\title{
International cooperation on migration: what do domestic publics want?
}

Alina Vrânceanu, Tobias Heidland, Martin Ruhs, and Elias Dinas*

21 May 2021

\begin{abstract}
What preferences do people have for cooperation between high and lower-income countries on irregular migration and refugee protection? Despite the increase in the number and breadth of crosscountry cooperation agreements in this policy area, we know little about people's preferences for such policies. This paper addresses this question in the context of the EU-Turkey 'migration deal' agreed in 2016. We conduct cross-country conjoint experiments in Germany, Greece, and Turkey to shed light on the types of policies that generate public support for cross-country cooperation on irregular migration and refugee protection. Our respondents are favorable to several core features of the current EU-Turkey migration deal regarding the return of irregular migrants, financial aid to refugees in Turkey, and the intensity of Turkish border controls. We also find evidence of public support for cooperation on resettlement and EU support to Greece to deal with migration. In certain aspects of cooperation, public preferences seem to respond to interactions between policy dimensions. For example, German public support for relocating refugees from Greece is enhanced if there are stepped-up border controls in Turkey. These findings have important implications for research on public attitudes to asylum and migration policies, 'migration diplomacy' in international relations, and public backlash against international cooperation more generally.
\end{abstract}

Keywords: cross-country cooperation; migration; EU-Turkey agreement; conjoint analysis.

\footnotetext{
* Alina Vrânceanu, Elias Dinas, Martin Ruhs: European University Institute. Tobias Heidland: Kiel Institute for the World Economy, Kiel University, and IZA. The research for this paper is part of the Mercator Dialogue on Asylum and Migration (MEDAM), an international research and policy initiative funded by Stiftung Mercator. We would like to thank Brian Burgoon, Andrew Geddes, Matthias Lücke, Saime Ozcurumez, Alan Sule and Olivia Sundberg for their helpful comments. Alsena Kokalari, Foteini-Maria Vassou and Asli Okyay provided excellent research assistance.
} 


\section{Introduction}

High-income countries have a long history of cooperating with lower-income countries to reduce irregular migration and contain refugees in or near their regions of origin (see e.g. Fitzgerald 2019). The fundamental idea underpinning many of these policy cooperations is that rich countries provide financial assistance to lower-income countries of origin and transit in exchange for these countries' efforts to host refugees and/or reduce irregular out-migration to high-income countries (e.g. Adamson and Tsourapas 2019). In recent years, growing numbers and politicization of refugees (e.g. Nawyn 2018; Krzyzanowski et al. 2017) have led to increased attempts to expand such cooperative policies further, as shown, for example, by the US migration agreements with Guatemala, El Salvador, and Honduras announced in 2019.

Despite the high salience of migration and refugee issues in many high-income countries, there is little systematic research on public preferences vis-à-vis the long-standing and growing phenomenon of cooperation between rich and lower-income countries on irregular migration and refugee protection. While there is by now a voluminous literature on public attitudes toward asylum seekers (e.g. Hangartner et al. 2019, Steinmayr 2020, Dinas et al. 2019, Vertier et al. 2020, Gessler et al. 2021), there is much more limited evidence on public preferences towards attempts to regulate refugee inflows and protection in high-income countries (Jeannet et al. 2021). The small body of research that has analyzed public preferences for cross-country policy cooperation on migration issues has focused on cooperation among rich host countries (e.g. Bansak et al. 2017; Heizman and Ziller 2020). Therefore, our understanding of the types of migration policy cooperation the public supports is limited.

One reason for the current gap in the literature is that cross-country cooperation agreements are hard to analyze because they are inherently multidimensional. Thus, a comprehensive understanding of public support for such cooperation requires exploring public preferences not only across countries, but also across multiple dimensions of cooperation. In particular, one has to examine: (1) how specific dimensions of cooperation affect public support for the overall policy cooperation package; (2) how these effects differ across the countries involved and affected by the cooperation; and (3) whether there are relevant interactions between dimensions of cooperation.

We begin to address this gap in existing research by relying on a specific instance of migration policy cooperation between the European Union (EU) and non-EU countries, namely the 2016 EU- 
Turkey Statement (commonly referred to as the EU-Turkey “deal”). This setting allows us to identify the most relevant dimensions of cooperation, as it represents the most developed cooperation agreement between the EU and a non-EU country on migration in recent years. We then conduct original surveys in which we embed a conjoint experiment in Greece, Turkey, and Germany. These are the core countries most involved in and affected by the 2016 EU-Turkey deal. Due to its geographical location at the EU external borders, Greece represents one of the main entry points to Europe for asylum-seekers and migrants. It has been strongly affected by the 2015-16 refugee crisis, bearing much of the burden of processing asylum claims and managing reception centers. On the other hand, Turkey was strongly affected by significant refugee inflows generated by the war in Syria. It currently hosts 3.6 million registered Syrian refugees (UNHCR, 2020²) and committed, in the context of the 2016 EU-Turkey agreement, to take measures to reduce the outflows of irregular migrants to Europe. Finally, Germany was affected indirectly by secondary movements of asylum-seekers and migrants transiting through Turkey and Greece. ${ }^{3}$ It also played a major role in the negotiation of the 2016 EU-Turkey agreement (e.g. Smeets and Beach 2020).

We approach the analysis without strong priors about which specific policy features will produce stronger effects on public support for cooperation. Instead, we remain relatively agnostic, trying to include in the conjoint all the agreement's salient dimensions. That said, we do have three general expectations that we explore in our analysis. First, we expect that some cooperation will be preferred to no cooperation simply because the latter implies high levels of uncertainty and people seek to minimize uncertainty in their interactions. Second, we expect public policy preferences to differ in at least some aspects across the three countries because of their different roles as countries of migrants' transit and/or destination. Third, because the cooperation's impacts on each of the three countries will depend, at least in part, on policy commitments made by the other countries, we expect interactions between policy features across cooperation's different dimensions. These three expectations are not used as specific hypotheses to be tested against the null but rather serve as guidance to structure our empirical analysis.

Understanding public policy preferences matters for the political legitimacy of migration and refugee policy cooperation between high and low-income countries and for its longer-term sustainability. While public policies may not always reflect public attitudes, research has shown that highly salient policies tend to be responsive to public policy preferences (see e.g. Rasmussen,

\footnotetext{
${ }^{2}$ See https://www.unhcr.org/tr/en/unhcr-turkey-stats

${ }^{3}$ Germany registered around 1.2 million asylum applicants in 2015 and 2016. Source: Eurostat (migr_asyappctza). https://ec.europa.eu/eurostat/databrowser/view/migr_asyappctza/default/table?lang=en
} 
Reher, and Toshkov 2019; Burstein 2003), including on issues of foreign policy (e.g. Soroka 2003) and migration (e.g. Böhmelt 2019). In particular, to make sense of the (in)stability of cooperative migration policies over time, it is important to understand whether and how public preferences differ between voters in countries on different sides of the cooperation, and how public support for a particular policy measure implemented by one country is linked to policy measures implemented by the other country in the agreement.

We find that respondents support certain forms of policy cooperation on irregular migration and refugee protection. While respondents in destination countries (in our study Greece and Germany) have preferences for stronger border controls by the transit country (Turkey), we also see support for several policy features aimed at protecting refugees and asylum seekers, such as refugee resettlement (although some robustness checks confirm this finding in Germany only), financial support for refugees, while rejecting "pushbacks" (i.e. the practice of sending irregular migrants back to the transit or origin country without first examining their applications for asylum).

Moreover, respondents in Turkey support receiving greater support from European countries to help the refugee population that their country hosts. Ultimately, our results suggest that the public cares about reciprocity and responsibility-sharing between countries on different sides of the agreement.

Our study contributes to the literature on attitudes toward asylum seekers and other migrants by shedding light on public preferences for policies that regulate flows of migrants and asylum seekers. We also add to the emerging research on "migration diplomacy," which analyses how and why countries cooperate on international migration and refugee protection by bringing in a focus on the policy preferences of domestic publics. The paper also contributes to ongoing policy debates about the current EU-Turkey cooperation on irregular migration and refugee protection, as well as to ongoing research on public backlash against international cooperation more generally (e.g., De Vries, Hobolt, and Walter 2021). In contrast to the highly divisive political debates about the agreement, we find that, when considering different types of cooperation, there is considerable public support for the status quo in most dimensions of the EU-Turkey Statement that we analyzed, with a few important exceptions and country differences.

\section{Theoretical and policy background}

In many high-income countries, preventing or reducing irregular migration has long been a policy priority (e.g. Cornelius et al., 2004), and its political importance has increased since the so-called 
"refugee crisis" in 2015-16. While irregular migrants - defined as those who cross borders and/or stay in the host country illegally - have always involved significant numbers of labor migrants (OECD 2020), over the past 25 years asylum seekers have in many countries joined this group of apparently 'unwanted migrants' whose immigration is often highly restricted and actively prevented through a range of migration control measures. This is partly, but not only, because the process of seeking asylum has been closely intertwined with processes of irregular migration. The 1951 Geneva Refugee Convention and the 1967 protocol relating to the status of refugees do not require countries to provide opportunities for people to travel legally to their territories to apply for asylum. Therefore, most forced migrants who wish to apply for asylum in high-income countries must do so by engaging in irregular migration which often involves long and dangerous journeys across land and/or sea borders of one or more 'transit-countries'.

In the late $20^{\text {th }}$ and early $21^{\text {st }}$ centuries, when the scale of global displacement experienced spikes, the objectives of most high-income countries' policies towards asylum seekers and refugees began to shift, away from providing permanent or temporary protection in their own countries to 'regional containment' of refugees and other migrants in lower-income countries of transit or origin (see e.g. Shacknove 1993). This fundamental policy shift is often described as the rise of the "deterrence paradigm" (e.g. Gammeltoft-Hansen and Tan, 2017). Policy cooperation with lower-income transit countries has been at the heart of high-income countries' new containment approach toward asylum seekers and refugees.

Although the designs of cooperative containment policies (CCPs) vis-à-vis irregular migrants and asylum seekers have varied in practice, they are fundamentally about a 'tit-for-tat exchange of cash for migration control' (Adamson and Tsourapas 2019, 121). A minimal agreement thus involves the high-income country providing financial assistance to the lower-income transit country to help control migration and restrict outflows of migrants. Examples include US assistance to many Latin America countries to help strengthen borders controls (e.g. Fitzgerald 2019) and Italy's first informal agreements with Libya in the early 2000s which provided Italian financial support for Libya to strengthen 'border management' including the Libyan coast guard's efforts to intercept migrants attempting to cross the Mediterranean to reach Europe (Paoletti 2011). Many CCPs also include commitments by the transit country to readmit migrants whose asylum applications have been rejected in the high-income country. The return and readmission agreements that European countries have tried to negotiate, and in a few cases agreed, with non-EU countries over the past 20 years are a good example (e.g. Billet 2010; European Court of Auditors 2020). 
A third and more extensive form of cooperation involves substantial financial assistance and economic cooperation by the high-income country for the protection and socio-economic integration of refugees in the low-income country. For example, under the 'Jordan Compact', Jordan, host of large numbers of refugees, recently granted work permits to Syrian refugees in exchange for financial assistance and preferential trade terms from high-income countries (e.g. Betts and Collier 2017; Lenner and Turner 2019). Cooperation has in some cases also included a commitment by the high-income country to resettle a limited number of refugees directly from the low-income country. As discussed in more detail below, the migration cooperation agreed between the EU and Turkey in 2016 includes such a provision.

What explains the specific shape a CCP will take? Insights from international relations theory can help address this question. Taking a realist perspective, both the form and the longevity of a CCP can be expected to depend on instrumental considerations. A relatively recently emerged body of research on 'migration diplomacy' analyzes how the perceived national interests and power of state actors in inter-state bargaining are influenced by their respective positions in the migration system and, thus, by their different roles within the cooperation, i.e. as transit or origin countries where migrants are meant to be contained and in some cases also integrated, or as countries that provide financial assistance in return for non-admission of migrants (e.g. Adamson and Tsourapas 2019). At times of increasing concerns about the scale of immigration, especially irregular migration, in highincome countries, transit countries' ability to 'regulate' outflows of migrants to higher-income countries has given them increasing leverage in these cooperations (e.g. Greenhill 2010; Tsourapas 2017).

In addition to the relative power and interests of the countries involved, the design and stability of CCPs are likely to be influenced by moral considerations, stemming from ideas and norms relating to migration control and refugee protection. As suggested by recent work on realist constructivism (e.g. Barkin 2012), power and interests on the one hand and ideas and norms on the other are not mutually exclusive factors shaping international relations (also see Checkel 2013). Almost all highincome countries have signed the 1951 Geneva Convention on the Protection of Refugees. The idea of providing protection to those who need it, based on certain rules and criteria, has thus become a well-established international norm that, although not always respected by states can influence how national policy-makers formulate their policy preferences vis-à-vis CCPs. 
At the same time, the policy feedback literature (Stimson et al. 1995, Lax and Phillips 2009) leads us to expect that the way public opinion feels about CCPs will have some impact on their design.

But then the question of course is how does the public form beliefs about the CCPs? It is possible, although by no means clear, that a 'pragmatic approach' that balances instrumental and moral considerations not only underpins national policy-makers' preferences in inter-state bargaining but also encourages voters to support reciprocal policy cooperation between high and lower-income countries on irregular migration and refugee protection. Recent research on public preferences for (mainly unilateral) asylum and refugee policies in European countries suggests that Europeans prefer policies that provide protection to refugees but also impose policy controls through limits and conditions, as a way of reconciling competing logics of 'protection' and the 'perceived national interest' (Jeannet et al. 2021). We do not yet know whether and how such a balancing of moral and instrumental considerations also informs policy preferences for CCPs.

\section{The EU-Turkey Statement: Key Dimensions and Political Conflicts}

The cooperation agreed between the EU and Turkey in March 2016 has been a central part of the EU's response to the rapid increase in the number of asylum seekers and other migrants arriving in Europe in 2015. Most of this increase occurred along the so-called "East Mediterranean route," where migrants cross the Aegean Sea between Turkey and Greece before quickly moving on to other EU countries, especially Germany.

This gave rise to the new EU-Turkey cooperation on irregular migration and refugee protection negotiated between Turkey and several EU Member States (including Germany and Greece) and agreed between the European Union and Turkey in March 2016. Under the EU-Turkey Statement ${ }^{4}$, migrants who move irregularly from Turkey to the Greek islands and do not qualify for refugee protection in Greece may be returned to Turkey. Turkey also committed to taking "any necessary measures to prevent new sea or land routes for illegal migration opening from Turkey to the EU." In return, the EU agreed to support refugees in Turkey with $€ 6$ billion ${ }^{5}$ and to resettle refugees directly from Turkey under a 1:1 scheme that foresees that, for each Syrian migrant returned from the Greek islands to Turkey, one Syrian refugee will be resettled from Turkey to the EU. ${ }^{6}$ In

\footnotetext{
${ }^{4}$ See https://www.consilium.europa.eu/en/press/press-releases/2016/03/18/eu-turkey-statement/

${ }^{5}$ See the "EU Facility for Refugees in Turkey", https://ec.europa.eu/commission/presscorner/detail/en/ip 196694

${ }^{6}$ In addition to resettlement, the EU also made a conditional commitment to activate a Voluntary Humanitarian

Admission Scheme: "Once irregular crossings between Turkey and the EU are ending or at least have been substantially and sustainably reduced, a Voluntary Humanitarian Admission Scheme will be activated. EU Member States will
} 
addition to these four migration-related provisions, the EU made several conditional commitments on other policy issues of importance to Turkey.

Following the 2016 agreement, the numbers of migrants crossing from Turkey to Greece declined significantly: sea arrivals declined from 860,000 in 2015 to 170,000 in 2016 and about 30,000 in each of 2017 and 2018, before increasing again to 60,000 in 2019 and, following the outbreak of Covid19, dropping to fewer than 16,000 in $2020 .^{7}$ The agreement thus helped the EU achieve its core political objective of drastically reducing the number of asylum seekers and other migrants arriving in Greece and then moving on to other EU countries. It has also clearly benefited many refugees and migrants in Turkey who have received support from the EU's Facility for Refugees in Turkey that manages the EUR 6 billion in EU assistance. Yet, reactions to the agreement were not universally positive. Early surveys conducted in the summer of 2016 indicated that two thirds of Germans were against the EU-Turkey deal, ${ }^{8}$ while legal scholars questioned the agreement's democratic credentials and legal foundations. ${ }^{9}$ Using this deal as our case study, we ask what tradeoffs European publics are willing to make regarding policy packages aimed at regulating migrant flows. In what follows, we explain in detail the dimensions along which these trade-offs fall.

\section{Research Design}

Cross-country cooperation on irregular migration and refugee protection clearly involves multiple dimensions of policy cooperation. Conjoint experiments are particularly suited to study public preferences for such multidimensional objects (Hainmueller et al. 2014). We draw on the 2016 EUTurkey Statement and recent policy debates to identify (i) the key dimensions of policy cooperation on refugee protection and irregular migration and (ii) within-dimension variation in policy features, that we exploit in our conjoint experiment.

\footnotetext{
contribute on a voluntary basis to this scheme." (EU-Turkey Statement). We exclude this commitment from the core migration-related dimensions of the deal because it is voluntary.

${ }^{7}$ During the same period, land arrivals increased from about 4,900 in 2015 to 15,000 in 2019. See

https://data2.unhcr.org/en/situations/mediterranean/location/5179

${ }^{8}$ See Aljazeera's news coverage of the topic during the period: https:/www.aljazeera.com/news/2016/8/8/majority-ofgermans-against-eu-turkey-refugee-deal. (accessed on May 12, 2021).

${ }^{9}$ See blogpost by Mauro Gatti EJIL:Talk!, the official blog of the European Journal of International Law: https://www.ejiltalk.org/the-eu-turkey-statement-a-treaty-that-violates-democracy-part-1-of-2/ (accessed on May 12, 2021).
} 


\section{Policy dimensions and features}

Drawing on the 2016 EU-Turkey Statement, we identified four key dimensions of cooperation between the European Union and Turkey on refugee protection and irregular migration (to which we alluded briefly before). To the four dimensions we add a fifth about support offered by other EU Member States to Greece to deal with irregular migration. Table 1 presents an overview of the five dimensions and the corresponding policy features.

Returns. We consider two specific policy features regarding the return of migrants from Turkey to Greece. First, as mentioned before, the 2016 EU-Turkey Statement foresees the return to Turkey of migrants crossing irregularly to Greece and who do not qualify for asylum. Yet, despite the large scale of migrant arrivals on the Greek islands in 2015-16, very few migrants were returned to Turkey since 2016 (about 2,100 migrants, including only 404 Syrians, between April 2016 and March 2021, UNHCR 202010). Alleged practices of “pushbacks” by Greek border guards have instead been reported. Investigative accounts suggest that some migrants crossing the Aegean Sea were intercepted and "pushed back" to Turkey by the Greek Coast Guard without considering migrants' potential eligibility for protection, although the Greek government has persistently denied these allegations. ${ }^{11}$ NGOs in Greece and other EU countries have been highly critical of these alleged practices, as has been Turkey which also criticized the rest of the EU for turning a blind eye. ${ }^{12}$ Pushback practices are of course not limited to the EU-Turkey border and have been reported at other borders too (e.g. Human Rights Watch 2021'3; European Council 2018 ${ }^{14}$ ). The second potential policy feature we focus on is therefore the return to Turkey of migrants regardless of whether they qualify for asylum or not.

Financial assistance for refugees in Turkey. Under the current agreement, EU assistance for refugees in Turkey is provided primarily through cooperation with international humanitarian partner organizations such as UNHCR and the Red Cross. Some limited financial resources are provided to Turkish government departments, such as the Turkish Ministry of Education, for specific projects to assist refugees. In contrast, the Turkish government has made it clear that it

\footnotetext{
${ }^{10}$ See https://reliefweb.int/report/turkey/returns-greece-turkey-31-march-2020

${ }^{11}$ Kingsley, Patrick and Shoumali, Karam "Taking Hard Line, Greece Turns Back Migrants by Abandoning Them at Sea", The New York Times, 14 August 2020.

${ }^{12}$ See, e.g., https://www.euronews.com/2020/09/25/greece-accused-of-pushing-back-migrants-at-sea-to-turkey , https://www.infomigrants.net/en/post/30292/greek-ngos-denounce-inaction-over-illegal-migrant-pushbacks

${ }^{13}$ See https://www.hrw.org/news/2021/02/01/human-rights-watch-submission-special-rapporteurs-report-pushbackpractices-and

${ }^{14}$ See https://pace.coe.int/en/files/27728
} 
would much prefer direct budget support, i.e. EU financial assistance that is channeled directly to the Turkish government rather than via international humanitarian partner organizations. Recent interviews with German and EU policymakers suggest that such direct budget support for the Turkish government has never been on the cards as it goes against their idea of providing humanitarian assistance based on needs-assessments (Luecke et al 2021). In line with these provisions and the discussions surrounding them, we focus on two policy features: financial assistance via international organizations and NGOs working with refugees in Turkey and assistance directly to the Turkish government. Moreover, we add a third policy feature that implies no financial support.

Resettlement. Another key provision of the 2016 EU-Turkey Statement was the above-mentioned 1:1 mechanism. Yet, while the number of Syrian refugees resettled from Turkey to EU countries since 2016 has been significantly above the number of Syrian migrants returned from Greece to Turkey, it has remained relatively limited. Since April 2016, 28,300 Syrian refugees were resettled from Turkey to the EU involving twenty EU Member States. ${ }^{15}$ Most resettlement to the EU in recent years has been from Turkey and Syrians have been the largest group. ${ }^{16}$ Nevertheless, the 28,300 Syrians resettled from Turkey to the EU constitute less than 0.8 percent of Turkey's Syrian refugee population in 2020. While Turkey has called for an increase in these numbers ${ }^{17}$, EU countries including Germany, the largest host country of Syrians resettled from Turkey, have shown no signs of a willingness to increase drastically the scale of resettlement of refugees from Turkey (Luecke et al 2021). To reflect these different dynamics, we focus on three policy features. First, we include the ' $1: 1$ ' mechanism to capture current provisions in the agreement. Second, in line with the above-mentioned calls, inter alia from Turkey, to resettle higher numbers of refugees, we include the option of resettling each year $1 \%$ of the refugee population that Turkey is currently hosting (i.e. 36000 refugees). Third, we include the possibility of no resettlement whatsoever.

Turkish border controls. Increased border controls are at the heart Turkey's policies to deliver on its commitment in the EU-Turkey Statement. The 2015 EU-Turkey Joint Action plan that preceded the

\footnotetext{
${ }^{15}$ See https://ec.europa.eu/transparency/regdoc/rep/10101/2021/EN/JOIN-2021-8-F2-EN-MAIN-PART-1.PDF

${ }^{16} \mathrm{See}$ https://ec.europa.eu/info/strategy/priorities-2019-2024/promoting-our-european-way-life/statistics-migrationeurope en

${ }^{17} \mathrm{See}$ https://vestnikkavkaza.net/analysis/Turkish-diplomats-call-on-EU-to-share-refugee-burden.html
} 


\begin{tabular}{|c|c|c|}
\hline Policy Dimensions & Randomly Allocated Policy Features & Wording \\
\hline $\begin{array}{l}\text { I. Return of } \\
\text { migrants from } \\
\text { Greece to Turkey }\end{array}$ & $\begin{array}{l}\text { 1. [Status-quo:] Return only irregular migrants not } \\
\text { applying for asylum or whose applications are found } \\
\text { inadmissible. } \\
\text { 2. Return all irregular migrants without considering } \\
\text { applications for asylum ("pushbacks") }\end{array}$ & $\begin{array}{l}\text { Greece sends back only those migrants crossing irregularly from } \\
\text { Turkey who do not qualify for asylum. } \\
\text { Greece sends back all migrants crossing irregularly from Turkey, } \\
\text { even those who may qualify for asylum. }\end{array}$ \\
\hline $\begin{array}{l}\text { II. EU financial } \\
\text { support to help } \\
\text { refugees in } \\
\text { Turkey }\end{array}$ & $\begin{array}{l}\text { 1. No financial support } \\
\text { 2. [Status-quo:] Financial support to the Turkish } \\
\text { government to implement the agreement } \\
\text { 3. [Status-quo:] Financial support to IOs and NGOs } \\
\text { working with migrants in Turkey }\end{array}$ & $\begin{array}{l}\text { No financial support to the Turkish government or other } \\
\text { organizations helping refugees. } \\
\text { Financial support to the Turkish government to help refugees. } \\
\text { Financial support to international and non-governmental } \\
\text { organizations to help refugees in Turkey. }\end{array}$ \\
\hline $\begin{array}{l}\text { III. Resettlement } \\
\text { from Turkey to } \\
\text { EU }\end{array}$ & $\begin{array}{l}\text { 1. [Status-quo:] 1:1 resettlement } \\
\text { 2. No resettlement } \\
\text { 3. Unconditional, but limited resettlement (i.e. not } \\
\text { conditional on number of refugees returned from } \\
\text { Greece to Turkey) }\end{array}$ & $\begin{array}{l}\text { EU takes in one Syrian refugee for each irregular Syrian migrant } \\
\text { sent back by Greece to Turkey. } \\
\text { EU takes in no Syrian refugees from Turkey. } \\
\text { EU takes in } 1 \% \text { of the population of Syrian refugees in Turkey } \\
\text { each year (that is, } 36.000 \text { in } 2020 \text { ). }\end{array}$ \\
\hline $\begin{array}{l}\text { IV. EU support to } \\
\text { Greece to deal } \\
\text { with migration }\end{array}$ & $\begin{array}{l}\text { 1. Financial/operational support } \\
\text { 2. Relocation } \\
\text { 3. No support }\end{array}$ & $\begin{array}{l}\text { Financial and operational support. } \\
\text { Transfer of asylum seekers from Greece to other EU countries. } \\
\text { No support to Greece for dealing with migration. }\end{array}$ \\
\hline $\begin{array}{l}\text { V. Turkish } \\
\text { controls of border } \\
\text { with Greece }\end{array}$ & $\begin{array}{l}\text { 1. Regular border controls } \\
\text { 2. Enhanced border controls }\end{array}$ & $\begin{array}{l}\text { Standard border controls (e.g. document checks at ports) to } \\
\text { prevent irregular migration to the EU } \\
\text { Stepped up border controls (e.g. increased interception and } \\
\text { surveillance activities) to prevent irregular migration to the EU }\end{array}$ \\
\hline
\end{tabular}


2016 EU-Turkey Statement explained that Turkey intended to "strengthen the interception capacity of the Turkish Coast Guard, notably by upgrading its surveillance equipment, increasing its patrolling activity and search and rescue capacity, including through stepping up cooperation with EU Member States." Although the dynamics of irregular migration between Turkey and the EU are influenced by a range of factors (see e.g. Yldiz 2020), Turkey's implementation of stepped-up border controls is perceived to have played an important role in reducing irregular crossings from Turkey to Greece after March 2016 (e.g. European Commission 2021 ${ }^{18}$ ). Besides a policy feature implying enhanced border controls between Turkey and Greece, we include in our conjoint experiment the option of standard border controls (e.g. document checks at ports).

Support for Greece. Although not explicitly part of the 2016 EU-Turkey Statement, we add a fifth policy dimension on EU support for Greece. Greece currently benefits from financial and operational support. Despite repeated calls by the European Commission for more solidarity and responsibility-sharing among EU Member States in hosting people seeking protection, relocation of asylum seekers from Greece to other EU Member States has been very limited. Out of over 170,000 asylum seekers and refugees in Greece in 2019 ${ }^{19}$, only about 2,000 (most of them children) were relocated from Greece to other EU countries in $2020 .^{20}$ As a result, and despite the large EU assistance received, some Greek policymakers feel that they are "left alone by the EU" to deal with this issue (Luecke et al 2021). Building on this, we include three distinct policy features on EU support for Greece: (1) financial and operational support, (2) relocation and, as a benchmark against which these two options are to be compared: (3) no support.

\section{The conjoint experiment}

We conducted our cross-national conjoint experiment between January and February 2021 using national samples of the voting age population in Germany, Greece, and Turkey ${ }^{21}$ (see Table A1 in the Supplementary Material (SM) for summary statistics). After a short

\footnotetext{
${ }^{18} \mathrm{See}$ https://ec.europa.eu/transparency/regdoc/rep/10101/2021/EN/JOIN-2021-8-F2-EN-MAIN-PART-1.PDF

${ }^{19} \mathrm{See}$ https://reporting.unhcr.org/greece

${ }^{20} \mathrm{See}$ https://ec.europa.eu/home-affairs/news/2000-vulnerable-asylum-seekers-and-recognised-refugeesrelocated-year-greece en

${ }^{21}$ Our sample consists of 1336 respondents in Germany, 1327 respondents in Greece and 1259 respondents in Turkey (see the SM for further details on sampling).
} 
introduction that explained the conjoint tasks and defined the terms 'asylum seeker', 'refugee' and 'resettlement' (see SM for wording), respondents were presented with five pairs of hypothetical international cooperation agreements between the EU and Turkey on refugee protection and the management of irregular migration (hereafter, policy options). The experiment randomly varied the five dimensions of policy cooperation detailed above, each taking on one of multiple values (see Table 1). The order of five dimensions in the conjoint table was also randomized for each respondent but then remained fixed within respondents across the five conjoint tasks to ease the cognitive burden.

For each of the five pairs of policy options, we asked respondents to choose one policy option among the two they were presented with, and to rate both policy options on a seven-points scale. We use the choice item as our main dependent variable, and present results from robustness checks employing the rating variable as outcome variable in the Supplementary Material (see the 'Robustness checks' section). In our main empirical analyses, the dependent variable takes on the value of one if the respondent chose the policy option in the corresponding conjoint task or zero if the respondent did not choose it. Following Hainmueller et al. (2014), we compute average marginal component effects (AMCEs) to estimate the treatment effects. These can be interpreted as the change in the probability of choosing a 'policy option' when a given policy feature is compared to the baseline (Hainmueller et al. 2014, 19). The estimation procedure relies on a linear regression of the outcome variable on treatment indicators, with standard errors clustered by respondent. The Supplementary Material reports a series of diagnostic checks regarding the assumptions underlying conjoint analyses, and tests of row-order effects to address potential concerns about external validity (Hainmueller et al. 2014).

In a second step, we explore interaction effects between treatment variables. We follow the approach proposed by Egami and Imai (2019) to estimate the average marginal interaction effect (AMIE). This approach yields interaction effects whose relative magnitude is independent of the choice of baseline category. All our analyses were prespecified in a preanalysis plan registered at EGAP (Evidence in Governance and Politics). 


\section{Results}

We begin by presenting our results for the average effects of policy features on the probability that a specific policy package is chosen. In a second step, we present results from our empirical analyses of interaction effects between treatments.

\section{Average effects of policy features on public preferences}

We start by analyzing the average causal effects of policy features on the probability of choosing a policy option, relying on unweighted data (unless otherwise noted). Figure 1 shows the estimated average marginal component effects (AMCEs) with 95\% confidence intervals $^{22}$ separately for Germany, Greece and Turkey. The reference categories within each policy dimension, which are depicted by points without horizontal bars, broadly reflect the status quo (i.e. current provisions of the 2016 EU-Turkey deal). Marginal means showing levels of favorability towards each policy feature (Leeper et al 2019), including those that are set as reference categories, are shown in Figure A2 in the Supplementary Material.

Regarding the first dimension (returns), a policy option foreseeing the possibility for Greece to return all migrants crossing irregularly from Turkey (i.e., including those who may qualify for asylum) is estimated to reduce public support by about 8 percentage points in the German sample and 6 percentage points in the Greek sample. This feature does not affect the policy choice probability of the Turkish respondents. This suggests that respondents in Greece and Germany tend to oppose 'pushbacks', at least when compared to the status-quo policy of returning only those irregular migrants who do not qualify for asylum.

The second dimension refers to financial support for refugees in Turkey. We see that, compared to a policy where such support is channeled through international organizations and NGOs helping refugees in Turkey, a policy package that implies no financial support decreases policy acceptance. The estimated AMCE ranges from - 0.03 in Greece to -0.06 in

\footnotetext{
${ }^{22}$ To compute the AMCEs shown in Figures 1 and A7 and the marginal means shown in Figure A2, we employ the cregg R package (Leeper et al. 2020). The remaining analyses were conducted in Stata, estimating separately for each country - a linear regression of the choice (or rating) outcome on indicator variables for the five policy dimensions, with standard errors clustered at respondent level.
} 

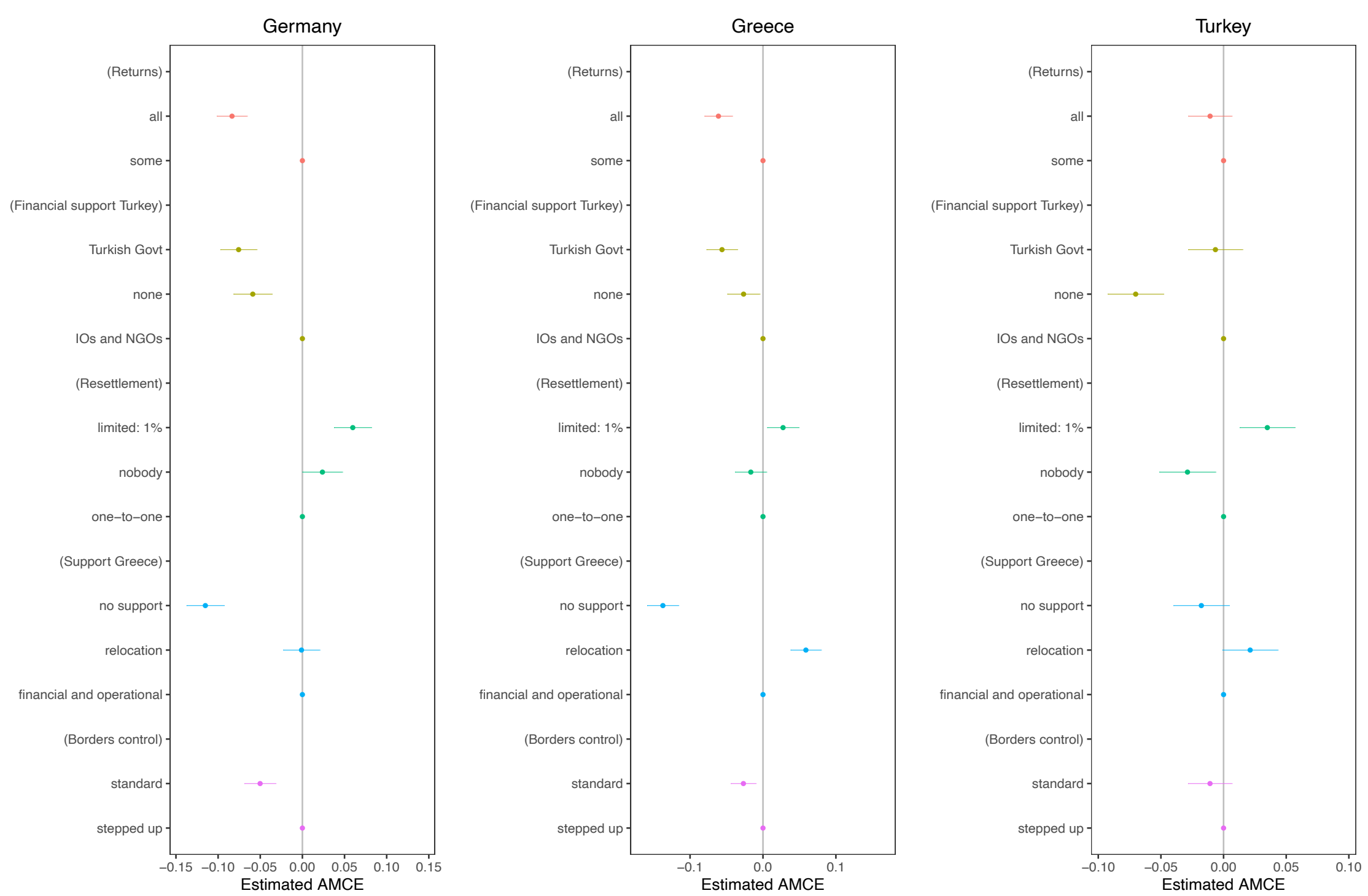

Figure 1: Effects of policy features on policy choice (point estimates with 95\% confidence intervals) 
Germany and -0.07 in Turkey. Moreover, policy packages that imply channeling financial support through the Turkish government negatively impact public opinion in Germany (estimated $\mathrm{AMCE}=-0.08$ ) and Greece (estimated $\mathrm{AMCE}=-0.06$ ), but not in Turkey.

Moving on to the third dimension, i.e. resettlement from Turkey, a policy package that involves the resettlement of $1 \%$ of the refugee population living in Turkey is more likely to be accepted than one foreseeing a 'one-to-one' resettlement mechanism. This is true in all countries: the estimated increase in policy support ranges from 3\% in Greece and Turkey to $6 \%$ in Germany. Unsurprisingly, the option of no resettlement decreases policy support in Turkey (estimated AMCE = -0.03). It does not, however, affect policy support in Greece. In the German sample, the estimated AMCE is roughly 0.024 points, with a p-value hovering around the 0.05 threshold, depending on whether weights are used ( $\mathrm{p}$-value $=0.053$ ) or not $(\mathrm{p} \text {-value }=0.049)^{23}$.

The fourth dimension refers to support to Greece to deal with migration. Compared to the baseline category of financial and operational support, a policy feature implying no support decreases public support in the Greek and German samples. It does not have a statistically significant effect in the Turkish sample. By contrast, relocation increases public support in the Greek sample (estimated AMCE $=0.06$ ), but it does not affect public preferences in the German and Turkish samples. Finally, switching from enhanced border controls between Greece and Turkey to a policy feature that foresees standard border controls decreases public support for the policy package in Greece and Germany. It has no effect among the Turkish respondents.

Overall, the picture emerging from these results is that of broad support for the status quo. Changing the status quo with respect to (1) return, (2) financial support for refugees in Turkey, and (3) border controls would decrease public support for the resulting cooperation agreement. On the two remaining dimensions, our results suggest that respondents tend to be more supportive of targeted reforms. First, compared to the current policy of 'one-to-one' resettlement, introducing the resettlement of $1 \%$ of the refugee population currently living in Turkey would increase public support in all three countries. Unsurprisingly, a policy of no

\footnotetext{
23 The weighting variable adjusts for age, gender and region.
} 
resettlement whatsoever would decrease public support in Turkey (but not in the other two countries). Second, compared to the current approach of granting financial and operational support to Greece, Greek respondents (but not the German respondents) tend to support relocation more.

\section{Conditionalities in policy attitudes}

In international policy cooperation, the attitudes towards offers to and expectations of participating countries may interact. For example, attitudes towards supporting a country in hosting refugees may be more positive if it will effectively contribute to the overarching aim of the policy cooperation in another dimension. To study such interactions, we explore the two-way interactions between the policy dimensions. ${ }^{24}$ The results, shown in Figure 2 Panels A-C, indicate relatively few interactions that are significant at the $95 \%$ significance level. ${ }^{25}$ The colors indicate the size of the estimated average marginal interaction effect, with red indicating negative interactions and blue indicating positive interactions. ${ }^{26}$

As specified in our pre-analysis plan, we had some priors regarding relevant interactions across policy dimensions. In particular, we anticipated that a policy option including EU financial support for refugees in Turkey and/or resettlement of refugees from Turkey should be more acceptable in the three countries if coupled with enhanced (instead of standard) border controls by the Turkish authorities. On average, we do not find strong evidence for this expectation.

However, a few interactions that were not pre-registered stand out. ${ }^{27}$ First, we find that attitudes towards supporting Greece can depend on the type of border controls implemented by the Turkish authorities. If enhanced controls are in place, Germans view relocation

\footnotetext{
${ }^{24}$ Interactions between policy levels are estimated following Egami and Imai (2019). To reflect the exploratory nature of our study, we assess all policy interactions jointly. We do not use regularization. Regularizing would allow model selection, focusing the attention on the most important interactions only. This could be implemented using a cost parameter to introduce a trade-off between parsimony in the number or interactions and value added by complexity.

${ }^{25}$ Implemented using two-sided tests and the confidence intervals account for the number of interactions tested. All interactions reported here are significant at the $95 \%$ significance level.

${ }^{26}$ The interaction effects are symmetric, i.e., the interactions between level 5-1 and 1-2 is identical to the interaction between 1-2 and 5-1. Only half of the matrix is therefore reported.

${ }^{27}$ We only report the strongest interaction effects here that would survive measures to restrict the false discovery rate.
} 
support for Greece more favorably (AMIE $=0.03$ ). This suggests that with a more closely sealed Turkish-Greek border (hence, lower inflows to Greece), German respondents will be more willing to support Greece through relocation. This interaction may suggest that the German respondents do not want to risk creating a "pull effect" through relocation. However, for Greece this means that Germans are more willing to provide support through relocation when it is needed less because there are lower inflows.

The second important finding is related to the interactions between policy dimensions regarding the support Turkey receives, namely resettlement and financial support but the implications differ markedly between Germany and Greece. In Germany, resettling 1\% of the population from Turkey and allocating financial support to refugees in Turkey through IOs and NGOs interact positively. Either of these is the favorite option within its respective policy dimension. If both are jointly present, the policy is a further 3 percentage points more likely to be preferred by the respondents in Germany. This suggests complementarity. By contrast, Greek respondents show preferences for substitution between ways of supporting Turkey: we find positive interactions between having resettlement and no financial support and, conversely, between having financial support and no resettlement, ${ }^{28}$ i.e. Greek respondents prefer policies that include either aspect but not both.

Thus, these results indicate public support for a two-pronged EU strategy for supporting Turkey, where Greece and EU destination countries such as Germany take on different roles: providing EU financial support that reaches beneficiaries without the risk of directly bolstering the current (critically viewed) Turkish government, financed by contributions from all EU member states; and resettling people directly from Turkey to Germany, where the burden of hosting refugees is felt much less strongly than in Greece. In addition, there is scope to relocate people from Greece to Germany if the Turkish-Greek border remains firmly controlled.

\footnotetext{
${ }^{28}$ AMIEs for no resettlement and financial support via the Turkish government or IOs and NGOs are 0.0242 and 0.0339 , respectively. For no financial support and $1 \%$ resettlement or one-to-one resettlement, AMIEs are 0.0255 and 0.0326 , respectively. All are significantly different from the baseline AMIE that reflects the status quo, i.e., one-to-one and support via IOs and NGOs.
} 


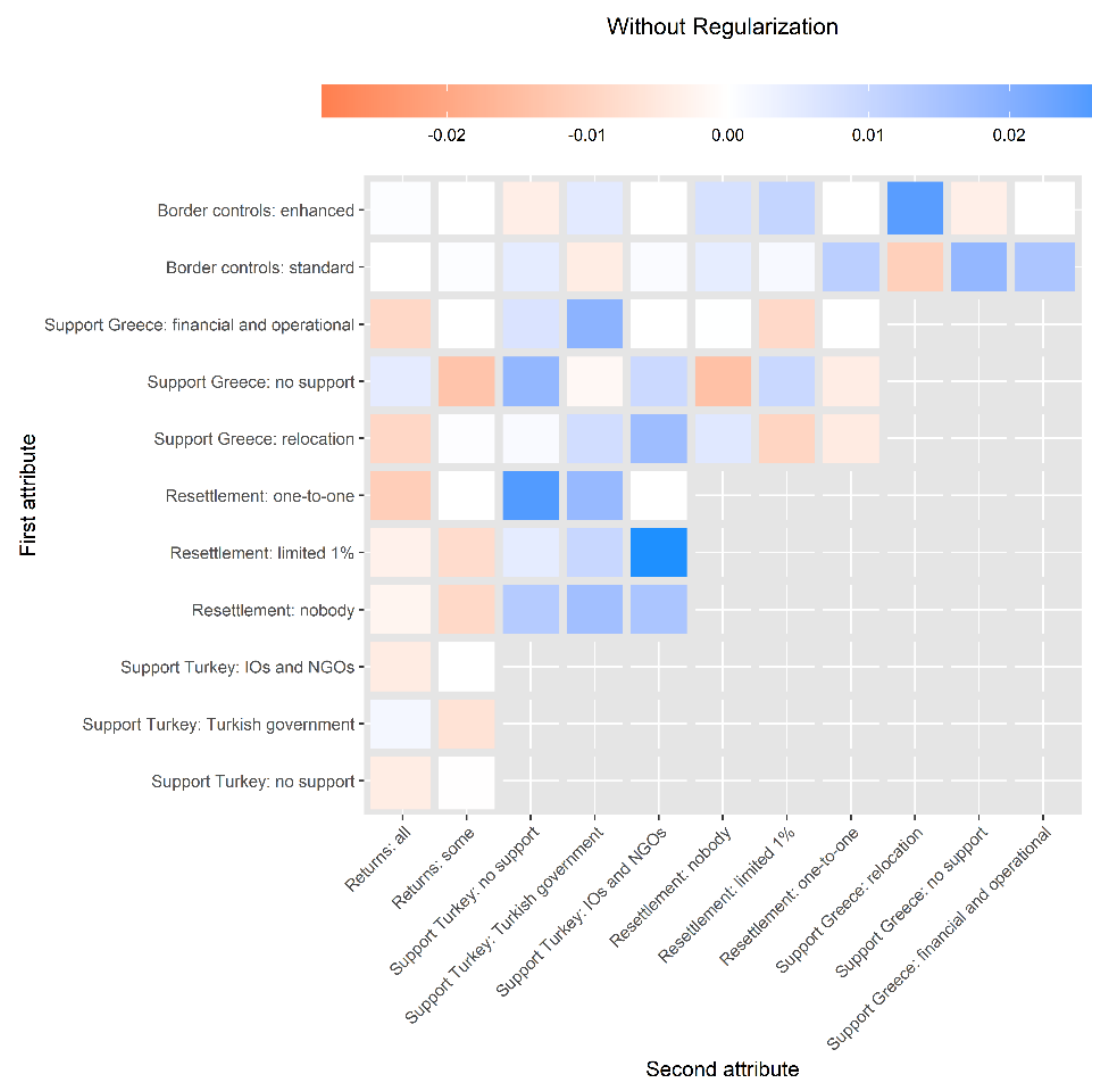

Figure 2-A: Average Marginal Interaction Effects Between Policy Features in Germany

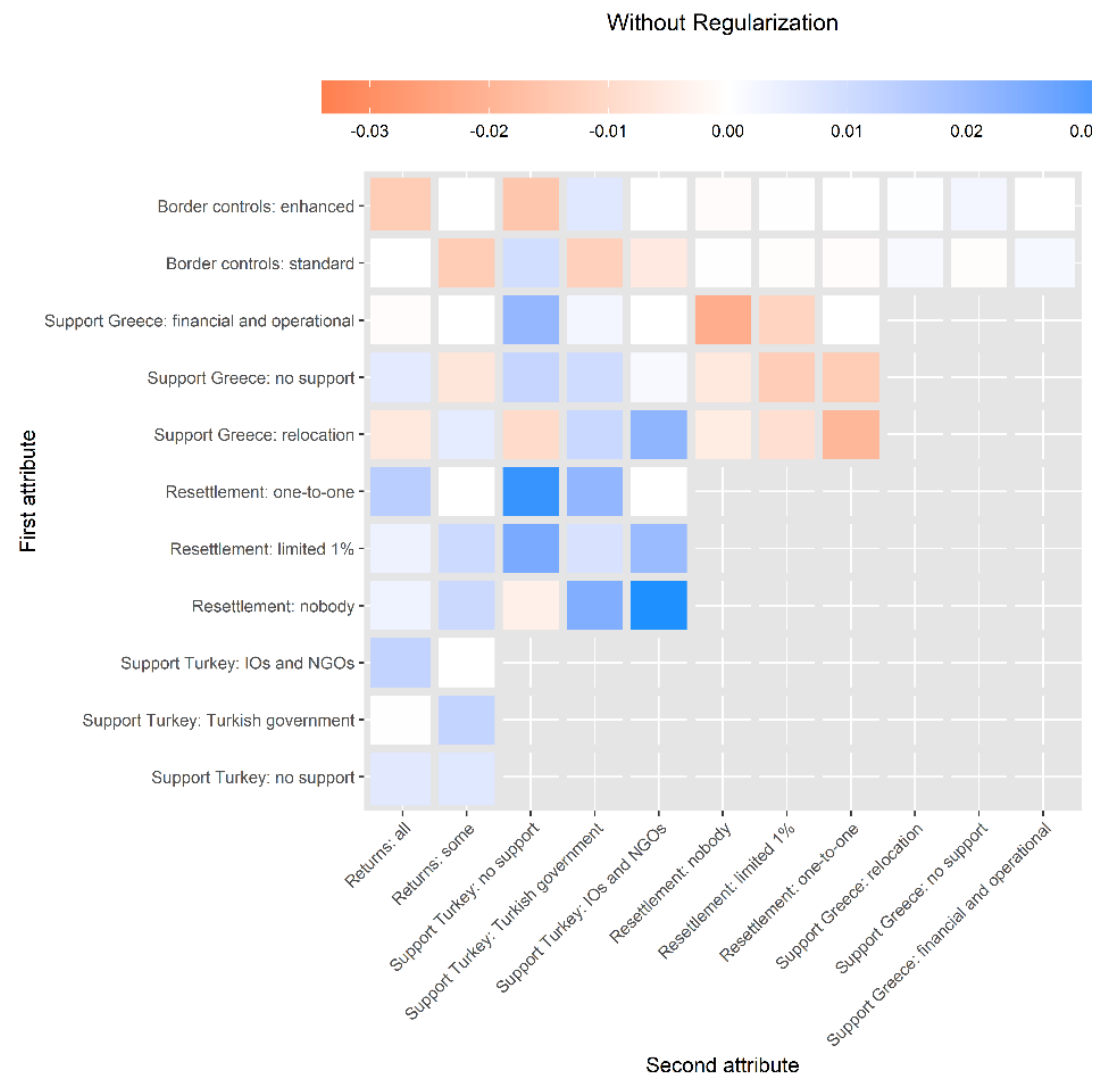

Figure 2-B: Average Marginal Interaction Effects Between Policy Features in Greece 


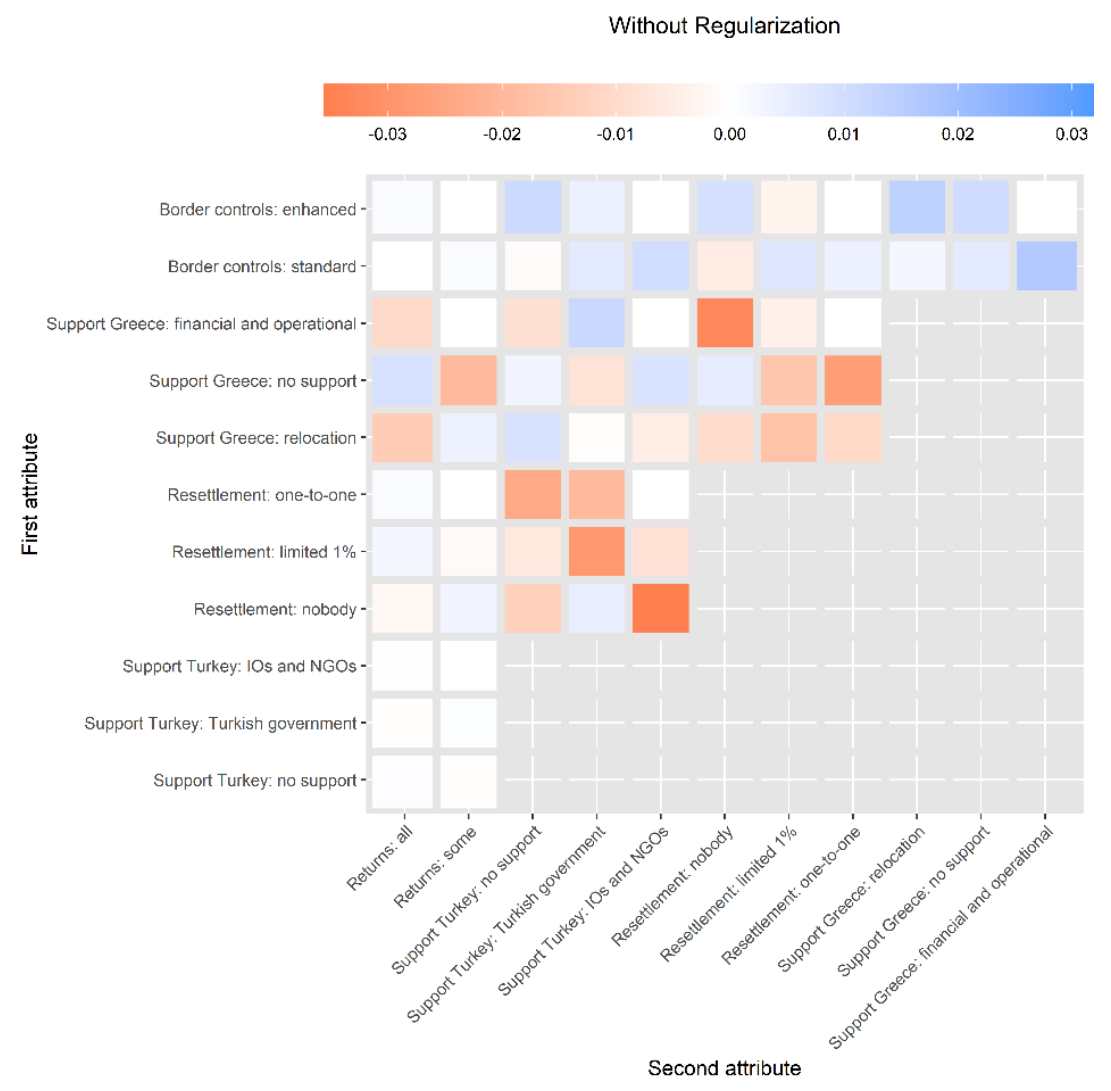

Figure 2-C: Average Marginal Interaction Effects Between Policy Features in Turkey

\section{Discussion and conclusions}

High-income countries increasingly strive for cross-country policy cooperation with lowerincome transit countries on irregular migration and refugee protection, yet there has been a lack of research on how the public thinks about such policies. Focusing on the EU-Turkey 'migration deal' agreed in 2016, we find public support for cross-country policy cooperation on irregular migration and refugee protection. Our respondents in Germany, Greece, and Turkey support the status quo in most dimensions of the EU-Turkey cooperation that we analyzed, with a few important exceptions and country differences.

Our findings have several theoretical and policy implications. First, public preferences for cross-country cooperation on these issues may be driven by a mix of moral and instrumental considerations, broadly reflecting findings from related fields such as public preferences for foreign aid (Heinrich and Kobayashi 2018). In the destination countries covered by our study, 
Greece and especially Germany, voters tend to oppose policies that involve blanket restrictions on access to asylum, such as returning anyone seeking protection without first hearing their case. They also tend to support the annual resettlement of non-negligible numbers of recognized refugees and to prefer policies that entail aid for refugees in Turkey channeled via IOs or NGOs. Moral considerations related to refugee protection appear thus to shape preferences for cross-country cooperation to a certain degree. At the same time, we find that German and Greek respondents support stronger border controls by the Turkish authorities. Unsurprisingly, Turkish respondents tend to oppose policies that fail to ensure financial aid from European host countries. This suggests that instrumental considerations may also be at play, further shaping public preferences.

Second, our results also suggest that domestic publics may care about reciprocity and burdensharing. We find that German respondents prefer backing Greece either through relocation or through financial and operational support, and supporting Turkey financially. Even the Greeks, historically not expected to favor concessions to Turkey, show a small but significant preference for policies under which Turks receive financial support for hosting refugees through NGOs and IOs and policies that involve resettlement from Turkey to the EU. In Turkey, voters find EU financial support via humanitarian organizations (rather than the Turkish government) more acceptable if there is resettlement of refugees from Turkey to the EU. We interpret these results as evidence that concerns about reciprocity and responsibilitysharing underpin public preferences for cross-country policy cooperation.

Third, our results suggest that the public also cares about the channel through which financial aid is allocated. We find that allocating aid for refugees via the Turkish government decreases public support among our German and Greek respondents. This suggests that people may associate the Turkish government with actions that often characterize 'nasty' regimes (Heinrich and Kobayashi 2018), such as crackdowns on media or opposition, that have been found to decrease support for foreign aid, highlighting thus some voters' reservations about cooperation with the Turkish state.

Finally, our study also speaks to recent research on the growing public backlash against international cooperation (De Vries, Hobolt, and Walter 2021). Migration is perceived as a challenge to the contemporary global order, in particular because of the nature of domestic politics on this issue (Goodman and Schimmelfennig 2020). However, our results suggest 
that certain types of cross-country cooperation can be appealing to domestic publics. We do not find consistent public support for policy features that imply a lack of engagement with partner countries on refugee protection and migration management, except an opposition in Germany and Greece to allocate aid for refugees via the Turkish government. On the contrary, domestic publics in our EU countries appear to support several policy features of the current cooperation agreement between the EU and Turkey concerning the return of irregular migrants, border controls, and financial support to refugees in Turkey via international organizations and NGOs.

The specific cooperation arrangement we focused on in our empirical analysis has been in place for more than five years. It is possible that what we may be capturing are positive feedback effects (De Vries, Hobolt, and Walter 2021:21). In fact, a recent analysis of the 2016 EU-Turkey Statement's political consequences suggests that it led to a reduction in antiimmigrant sentiment and voting for the radical right populist party AfD in Germany. The most likely mechanism is that it enhanced a sense of control and boosted trust in political leadership's ability to manage the refugee crisis (Solodoch 2021). This dynamic may give weight to the view that the agreement had, in turn, positive feedback effects on public support for (some of) its key dimensions. However, our results also suggest that there may be room for increased cooperation, particularly on the resettlement of refugees from Turkey to European countries. Resettling each year $1 \%$ of Turkey's refugee population seems to be an acceptable policy in all the three countries we study (although, when focusing on the rating outcome, this finding is only confirmed in Germany, see robustness checks in the SM). That policy goes beyond the current one-to-one mechanism and it may suggest that citizens care about greater responsibility-sharing in this particular area (Bansak et al. 2017). 


\section{References}

Adamson, Fiona and Gerasimos Tsourapas. 2019. Migration Diplomacy in World Politics. International Studies Perspectives 20: 113-128

Barkin, J. Samuel. 2012. Realist Constructivism. Rethinking International Relations Theory. Cambridge University Press

Betts, Alexander and Paul Collier. 2017. Refuge. Transforming a Broken Refugee System. Allen Lane

Bilet, Carole. 2010. EC Readmission Agreements: A Prime Instrument of the External Dimension of the EU's Fight against Irregular Immigration. An Assessment after Ten Years of Practice. European Journal of Migration and Law 12(1): 45-79

Bansak, Kirk, Jens Hainmueller, and Dominik Hangartner. 2017. Europeans support a proportional allocation of asylum seekers. Nature Human Behaviour 1, 0133.

Burstein, Paul. 2003 The Impact of Public Opinion on Public Policy: A Review and an Agenda. Political Research Quarterly 56(1): 29-40

Böhmelt, Tobias. 2019. How public opinion steers national immigration policies. Migration Studies, Early View https://doi.org/10.1093/migration/mnz039

Campbell, Andrea. 2012. Policy Makes Mass Politics. Annual Review of Political Science 15: 333-351.

Checkell, Jeffrey. 2013. Theoretical Pluralism in IR: Possibilities and Limits (Chapter 9. 220 - 242) in Sage Handbook of International Relations, 2nd Edition, 2013.

Cornelius, Wayne, Takeyuki Tsuda, Philip Martin and James Hollified. 2004. Controlling Immigration: A Global Perspective, Stanford University Press

De Vries, Catherine, Sara B. Hobolt, and Stefanie Walter. 2021. Politicizing International Cooperation: The Mass Public, Political Entrepreneurs, and Political Opportunity Structures. International Organization 1-27. Doi: 10.1017/S0020818320000491

Dinas, Elias, Konstantinos Matakos, Dimitrios Xefteris, and Dominik Hangartner. 2019. Waking up the golden dawn: does exposure to the refugee crisis increase support for extreme-right parties?. Political Analysis 27(2): 244-254.

Egami, Naoki, and Kosuke Imai. 2019. Causal Interaction in Factorial Experiments: Application to Conjoint Analysis. Journal of the American Statistical Association 114 (526): 529-40.

European Court of Auditors. 2020. EU migrant return policy - cooperation with third countries on readmission, available here 
https://www.eca.europa.eu/Lists/ECADocuments/AP20 07/AP Migrant return policy E

N.pdf (accessed on 7 April 2021)

Fitzgerald, D. 2019. Refuge Beyond Reach: How Rich Democracies Repel Asylum Seekers, Oxford University Press

Gammeltoft-Hansen, Thomas and Nikolas F. Tan. 2017. The End of the Deterrence Paradigm? Journal on Migration and Human Security 5(1): 28-56.

Gessler, Theresa, Gergő Tóth, and Johannes Wachs. 2021. No country for asylum seekers? How short-term exposure to refugees influences attitudes and voting behavior in Hungary. Political Behavior 1-29. https://doi.org/10.1007/s11109-021-09682-1

Goodman, Sara Wallace, and Frank Schimmelfennig. 2020. Migration: a step too far for the contemporary global order? Journal of European Public Policy 27(7): 1103-13.

Greenhill, Kelly. 2010. Weapons of Mass Migration: Forced Displacement, Coercion, and Foreign Policy. Cornell University Press. Ithaca.

Hainmueller, Jens, Daniel J. Hopkins, and Teppei Yamamoto. 2014. Causal Inference in Conjoint Analysis: Understanding Multidimensional Choices via States Preferences Experiments. Political Analysis 22 (1): 1-30.

Hangartner, Dominik, Elias Dinas, Moritz Marbach, Konstantinos Matakos, and Dimitrios Xefteris. 2019. Does exposure to the refugee crisis make natives more hostile?. American Political Science Review 113(2): 442-455.

Heinrich, Tobias, and Yoshiharu Kobayashi. 2018. How Do People Evaluate Foreign Aid to 'Nasty' Regimes? British Journal of Political Science 50: 103-127.

Heizmann Boris and Ziller Conrad. 2020. Who Is Willing to Share the Burden? Attitudes Towards the Allocation of Asylum Seekers in Comparative Perspective. Social Forces 98(3): 1026-1051.

Jeannet, Anne-Marie, Heidland, Tobias, and Martin Ruhs. 2021. What asylum and refugee policies do Europeans want? Evidence from a cross-national conjoint experiment.

European Union Politics, Early view

Krzyżanowski, Michał, Anna Triandafyllidou and Ruth Wodak. 2018. The Mediatization and the Politicization of the "Refugee Crisis" in Europe. Journal of Immigrant \& Refugee Studies 16(1-2): 1-14

Lax, Jeffrey R., and Justin H. Phillips. 2009. Gay rights in the states: Public opinion and policy responsiveness. American Political Science Review 103(3): 367-386. 
Lenner, Katharina and Lewis Turner. 2019. Making Refugees Work? The Politics of Integrating Syrian Refugees into the Labor Market in Jordan. Middle East Critique 28(1): $65-95$

Leeper, Thomas J., Sara B. Hobolt and James Tilley. 2020. Measuring Subgroup Preferences in Conjoint Experiments. Political Analysis 28: 207-21.

Lücke, Matthias, Alberto Horst Neidhardt, Saime Özçürümez, Martin Ruhs, and Olivia Sundberg Diez. 2021. EU-Turkey: Toward Sustainable Cooperation in Migration Management and Refugee Protection, MEDAM Assessment Report 2021, Kiel Institute for the World Economy

Nawyn, Stephanie. 2019. Refugees in the United States and the Politics of Crisis. In The Oxford Handbook of Migration Crises, edited by Cecilia Menjivar, Maria Ruiz, and Immanuel Ness. Oxford University Press

OECD. 2020. What are the Possible Policy Responses to Future Irregular Migration?. Migration Policy Debates No. 22, available here http://www.oecd.org/els/mig/migrationpolicy-debates-22.pdf (accessed on 7 April 2021)

Paoletti, Emanuela. 2011. Power Relations and International Migration: The case of Italy and Libya. Political Studies 59(2): 269-289

Rasmussen, Anna, Stefanie Reher, and Dimiter Toshkov. 2019. The opinion-policy nexus in Europe and the role of political institutions. European Journal of Political Research. 58: 412-434.

Shacknove, Andrew. 1993. From Asylum to Containment. International Journal of Refugee Law 5 (4): 521-522.

Smeets, Sandrino and Derek Beach. 2020. When success is an orphan: informal institutional governance and the EU-Turkey deal. West European Politics 43(1): 129-158.

Solodoch, Omar. 2021. Regaining Control? The Political Impact of Policy Responses to Refugee Crises. International Organization 1-34. Doi: 10.1017/S002081321000060.

Steinmayr, Andreas. 2021. Contact versus Exposure: Refugee Presence and Voting for the Far Right. The Review of Economics and Statistics 103(2): 310-327.

Stimson, James A., Michael B. MacKuen, and Robert S. Erikson. 1995. Dynamic representation. American Political Science Review 89(3): 543-565.

Soroka, Stuart. 2003. Media, Public Opinion, and Foreign Policy. Harvard International Journal of Press/Politics 8(1): 27-48

Tsourapas, Gerasimos. 2017. Migration Diplomacy in the Global South: Cooperation, Coercion and Issue-Linkage in Gaddafi's Libya. Third World Quarterly 38: 2367-2385. 
Vertier, Paul, Max Viskanic, and Matteo Gamalerio. 2020. Dismantling the 'Jungle': Migrant Relocation and Extreme Voting in France. Available at SSRN 2963641.

Yildiz, Ayselin. 2020. Impact of the EU-Turkey Statement on Smugglers' Operations in the Aegean and Migrants' Decisions to Engage with Smugglers. International Migration, Early View available here: https://onlinelibrary.wiley.com/doi/abs/10.1111/imig.12767 


\section{Supplementary material}

'International cooperation on migration: what do domestic publics want?'

\section{Data collection and sample}

We fielded our online survey between January and February 2021 in Greece, Germany and Turkey. We chose the three countries as they were affected differently by the 2015 refugee crisis and the subsequent 2016 EU-Turkey Statement: Turkey and Greece as main countries of transit, and Germany as one of the main destination countries (see also text).

To conduct the survey, we partnered with the survey firm Respondi. Respondi recruits participants to their online panel via own opinion platforms and the telephone. Membership and participation in the online panel is voluntary and follows a double opt-in registration process. After completing the survey, participants received points, which can be traded in for cash transfers, vouchers or donations upon reaching a certain threshold.

For our study, Respondi sampled respondents from the population of eligible voters (nationals who are 18 years or older). To ensure similarity to population demographics in age, gender and residence, quota sampling was applied, with stratification by age (five age groups), gender and region (NUTS1 regions in Turkey and Germany, and NUTS2 regions in Greece). The response rates ranged from $25 \%$ in Turkey and $26 \%$ in Greece to $36 \%$ in Germany, which are comparable to similar studies (Bansak et al. 2016). The median length of interview (LOI) was around 8 minutes. The final samples included 1336 respondents in Germany, 1327 in Greece and 1259 in Turkey.

The survey received ethical clearance from the European University Institute's Ethics Committee. Participation in the survey was based on informed consent expressed by participants at the beginning of the questionnaire.

\section{Experimental design}

The survey was administered in the national languages. Upon agreeing to take part in the survey, participants first answered a series of questions measuring nationality, year of birth, gender and region of residence, followed by a series of attitudinal questions and vote choice recall. One of the attitudinal questions (tapping into support for the country's (potential) EU 
membership) was part of a separate survey experiment. Only respondents assigned to the control group in that survey experiment received the conjoint experiment.

The conjoint experiment relied on completely independent randomization. In other words, the randomization did not involve any restrictions on the possible combinations of features of cross-country cooperation. Participants were asked to evaluate five pairs of hypothetical 'cooperation agreements' between the EU and Turkey on matters of refugee protection and migration management. Figure A1 shows an example of a conjoint task. Below we include the wording of the introduction to the conjoint experiment.

\section{Introduction to conjoint tasks}

With your help, we seek to understand the preferences of [COUNTRY NATIONALITY] voters about cooperation between the European Union and Turkey on refugee protection and to reduce irregular migration.

We will present you with hypothetical policy options regarding cooperation between the European Union and Turkey on asylum and migration. Each time, we will present two potential policy options consisting of a bundle of different components. These policy options will differ in some, but not necessarily all components. For each pair of policy options, please tell us which of the two policies you would personally prefer. Even if you are not entirely sure, please indicate which of the two options you prefer. We will then ask you to rate both policy options.

We will repeat this task five times with five different pairs of policy options.

This exercise is purely hypothetical. Please remember that the European Union does already have instruments for cooperation with Turkey on refugee protection and to reduce irregular migration, the characteristics of which may or may not appear in the policy options you will see.

Please remember that we are interested in your personal opinion. There are no right or wrong answers.

\section{Definitions}

Before proceeding with the survey, please read carefully the definitions of terms we use in this survey.

A 'refugee' is a person who is in need of international protection, owing to a well-founded fear of persecution for reasons of race, religion, nationality, political opinion or membership in her/his country of citizenship and/or residence, and whose formal status as a refugee has already been recognized. 
An 'asylum seeker' is an individual who is seeking asylum (protection) in a country other than their own but whose application for refugee status has not yet been decided.

'Resettlement' is the transfer of recognized refugees from a non-EU country (such as Turkey) in which they have sought refuge to an EU Member State that has agreed to admit them.

\section{Diagnostics}

Following Hainmueller et al. (2014), we conducted a series of diagnostics. First, we tested whether the randomization actually produced well-balanced experimental groups. Regarding the conjoint attributes, Figure A3 confirms that the country samples are well-balanced in policy features. In terms of respondent characteristics, we conducted multivariate balance checks for age, gender, education and region. Table A2 shows the results (those for region not shown). Omnibus F-tests suggest that policy features are jointly insignificant, thus jointly balanced (at p-value $<0.05$ ) with respect to age, gender and region. Regarding education, we uncovered some imbalances in the German sample (but not in the Greek and Turkish samples). Yet, including education as covariate does not alter our findings (see Table A3 in the SM).

Second, we tested whether the assumptions underlying conjoint designs, namely the absence of carryover, profile, and order effects (Hainmueller et al. 2014), are met. Regarding the carryover effects, Figure A4 displays the AMCEs from models estimated separately by conjoint task. Here we are not particularly interested in differences in the magnitudes of treatment effects but whether the treatment effects display the same sign (direction) across conjoint tasks. This appears indeed to be generally the case (and when the AMCE in a particular conjoint task has the opposite sign, compared to results where are all tasks are pooled, the estimate is typically small and lacks statistical significance). We also formally tested the null hypothesis that the AMCEs for each attribute are identical across the conjoint tasks. Our results suggest that they are similar, except for the third policy dimension (i.e., resettlement) in the German sample, where the AMCE for the policy feature 'nobody' only reaches statistical significance in the first task but not in the remaining ones. Similarly, the AMCE for the feature ' $1 \%$ ' reaches statistical significance in the first three tasks but not in the remaining ones. However, given that - by design - the first task cannot be contaminated by carryover effects, we are confident that the treatment effects, that we uncover in the first task, are genuine. 
Figure A8 shows the time spent by respondents on each of the five conjoint tasks.

Unsurprisingly, as respondents progress in the conjoint experiment, they spend less time on a conjoint screen. This may be indicative of the fact that toward the end of the conjoint experiment the respondents become more familiar with the different policy features and need thus less time to process the information. This is consistent with recent research suggesting that, in the context of conjoint experiments with increasing complexity, respondents tend to incorporate new information in a selective fashion (Jenke et al. 2021). Likewise, they may require less time to process information they have already been exposed to.

Moving on to checks on profile order effects, we uncover that the effects of some conjoint attributes tend to vary depending on whether they appear in the first or the second policy option. However, the direction of the effects remains generally consistent, with the exception of 'relocation' (in dimension 4 - 'EU support for Greece') in the German sample. While the results shown in Figure 1 indicate that this policy feature does not affect public support in the German sample, these checks suggest that the treatment effect tends to be positive when the policy feature appears in the first policy option and negative when it appears in the second one (see Figure A5).

Finally, we checked whether the AMCEs differ as a function of attribute order. We encountered several interactions between conjoint attributes and their row order. This is the case for the 'returns' dimension in the Greek sample (the F-test for the joint significance of the interaction terms has a p-value of 0.09), the 'support for Greece' dimension in the Greek and Turkish samples ( $\mathrm{p}$-value $=0.07$ and 0.04 , respectively), and the 'border control' dimension in the German sample ( $p$-value $=0.03$ ). Importantly, here the direction of the effects remains consistent across rows, although several effects fail to reach statistical significance when presented at the bottom of the conjoint table (for the 'returns' dimension in the Greek sample and 'support for Greece' in the Turkish sample), the top of the conjoint table (for 'relocation' in the Greek sample), or in middle of the table ('border control' dimension in the German sample). These patterns are likely to reflect how respondents react to complex information in a conjoint set-up. However, the fact that the direction of the effects generally remains consistent throughout (see Figure A6) lends confidence to our findings. 


\section{Robustness checks}

We performed two robustness checks. First, in addition to choosing between hypothetical policy packages, respondents were asked to also rate each policy option on a scale from 1 to 7 , where 1 indicates that the policy option is rated as "extremely negative" and 7 indicates an "extremely positive" rating. We therefore tested whether our main findings (as detailed in Figure 1, which shows results from models with the choice outcome) are affected by the use of this alternative dependent variable. We follow Hainmueller et al. (2014) and rescale the ratings to vary from 0 to 1 before computing the AMCEs. The results, shown in Figure A7, are in most instances consistent with those we obtained from models where the dependent variable is the choice outcome, although the magnitude of the effects is smaller. In a few instances, however, the estimated effects no longer reach statistical significance (although the point estimates display the same sign as in the main models), deviating thus from the main models. This is the case with the effects of the following policy features: no resettlement and standard border controls (German sample), limited resettlement of $1 \%$ of the refugee population living in Turkey (Greek and Turkish samples), and no financial support to refugees in Turkey (Greek sample). By contrast, in the Greek sample, the effect of the option of no resettlement from Turkey reaches statistical significance at p-value $<0.05$ (AMCE $=$ 0.012), while the effect is not statistically significant in the main model. Similarly, in the Turkish sample, the effect of the option of returning all irregular migrants reaches statistical significance at $\mathrm{p}$-value $<0.05(\mathrm{AMCE}=-0.01)$, whereas it does not reach statistical significance in the choice models.

Note that roughly $10 \%$ of our pooled sample correspond to instances of inconsistencies between the choice and the rating outcome ${ }^{29}$ (that is, roughly $9 \%$ of German sample, $10 \%$ of the Greek sample and 14\% of the Turkish sample). In other words, respondents gave a lower rating to the policy option of their choice. Dropping these observations from our model with the rating outcome yields results similar to those in Figure 1, with one notable exception related to the effect of relocation which reaches statistical significance at p-value $<0.05$ in the Turkish sample (see Figure A9). Interestingly, close to $23 \%$ of the pooled sample correspond to instances where the two policy options are rated equally (ranging from 19\% in Greece to $22 \%$ in Turkey and 28\% in Germany).

\footnotetext{
${ }^{29} \mathrm{We}$ also counted the inconsistencies per respondent. We find that in the pooled sample about $66 \%$ of our respondents gave a consistent ranking in all five tasks, $20 \%$ in 4 tasks, $8 \%$ in 3 tasks only, and 5\% in 2 tasks at most.
} 
Second, given the relatively many respondents with tertiary education in our samples, in particular, in Turkey and Greece (see Table A1), we explored whether the effects we uncover differ across education groups. Although not pre-registered, this subgroup analysis allows us to assess whether our main findings (from models with the choice outcome) are driven by a particular category of respondents. Results from models with interactions between treatments (i.e. policy features) and education (coded as a dummy variable taking the value 1 for respondents with tertiary education and 0 otherwise) are shown in Table A4. We generally observe similar effects across the two subgroups, with the notable exception of a strong positive effect of the policy of no resettlement among non-tertiary educated German respondents. 


\section{Figures}

Suppose there were two policy options with the characteristics shown below. Please read these characteristics carefully.

If you would like to read the definitions of terms again, please click here.

\begin{tabular}{|c|c|c|}
\hline & POLICY OPTION A: & POLICY OPTION B: \\
\hline $\begin{array}{c}\text { Turkish controls of } \\
\text { border with Greece }\end{array}$ & $\begin{array}{c}\text { Standard border controls (e.g. document checks at ports) to } \\
\text { prevent irregular migration to the EU. }\end{array}$ & $\begin{array}{c}\text { Standard border controls (e.g. document checks at ports) to } \\
\text { prevent irregular migration to the EU. }\end{array}$ \\
\hline $\begin{array}{c}\text { EU support to Greece } \\
\text { to deal with migration }\end{array}$ & Financial and operational support. & Financial and operational support. \\
\hline $\begin{array}{c}\text { EU financial support to } \\
\text { help refugees in Turkey }\end{array}$ & $\begin{array}{c}\text { No financial support to the Turkish government or other } \\
\text { organizations helping refugees. }\end{array}$ & $\begin{array}{c}\text { No financial support to the Turkish government or other } \\
\text { organizations helping refugees. }\end{array}$ \\
\hline $\begin{array}{c}\text { Resettlement from } \\
\text { Turkey to EU }\end{array}$ & $\begin{array}{c}\text { EU takes in one Syrian refugee for each irregular Syrian } \\
\text { migrant sent back by Greece to Turkey. }\end{array}$ & $\begin{array}{r}\text { EU takes in 1\% of the population of Syrian refugees in Turkey } \\
\text { each year (that is, 36.000 in 2020). }\end{array}$ \\
\hline $\begin{array}{c}\text { Return of migrants } \\
\text { from Greece to Turkey }\end{array}$ & $\begin{array}{c}\text { Greece sends back only those migrants crossing irregularly } \\
\text { from Turkey who do not qualify for asylum. }\end{array}$ & $\begin{array}{c}\text { Greece sends back only those migrants crossing irregularly } \\
\text { from Turkey who do not qualify for asylum. }\end{array}$ \\
\hline
\end{tabular}

If you had to choose between the two policy options, which one would you prefer?

POLICY OPTION A

I would personally choose ...
POLICY OPTION B

Figure A1. Conjoint screen 
Germany

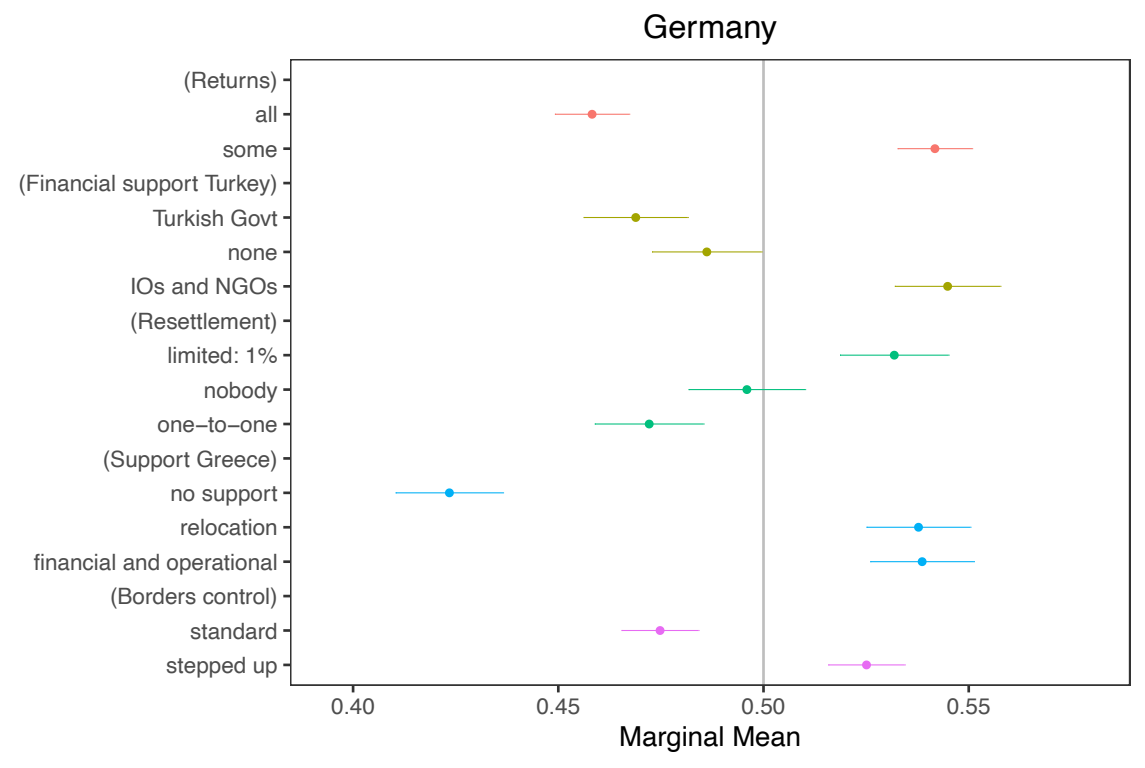

Turkey

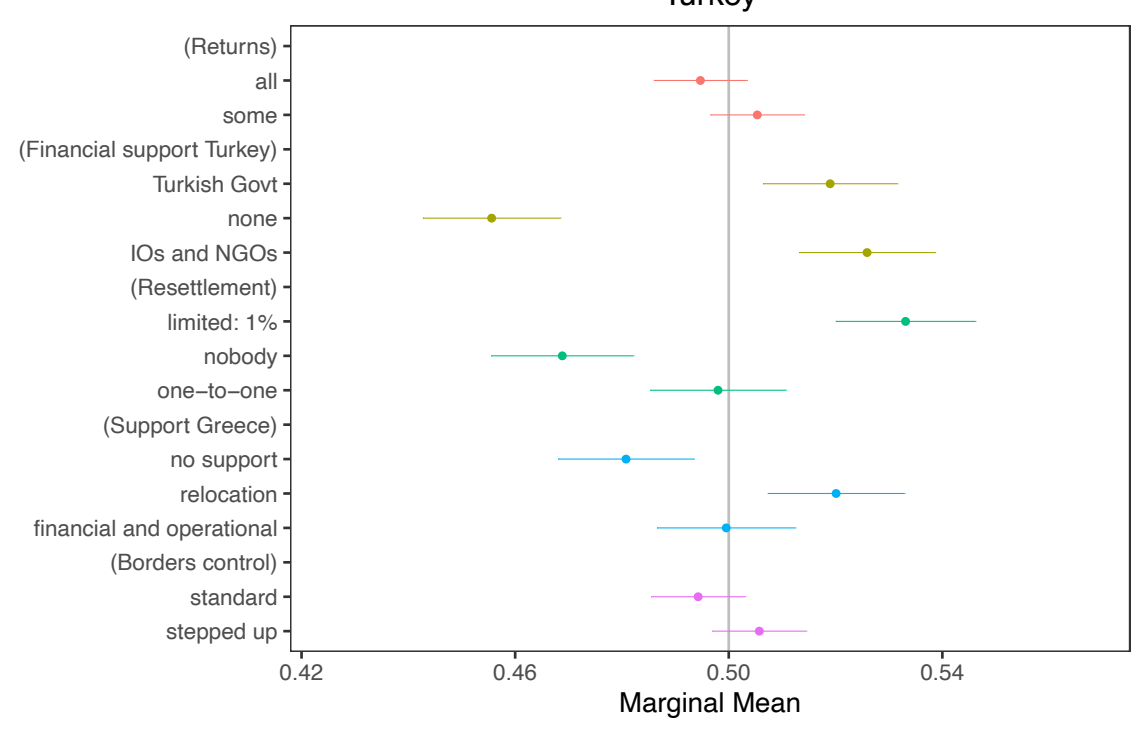

Greece

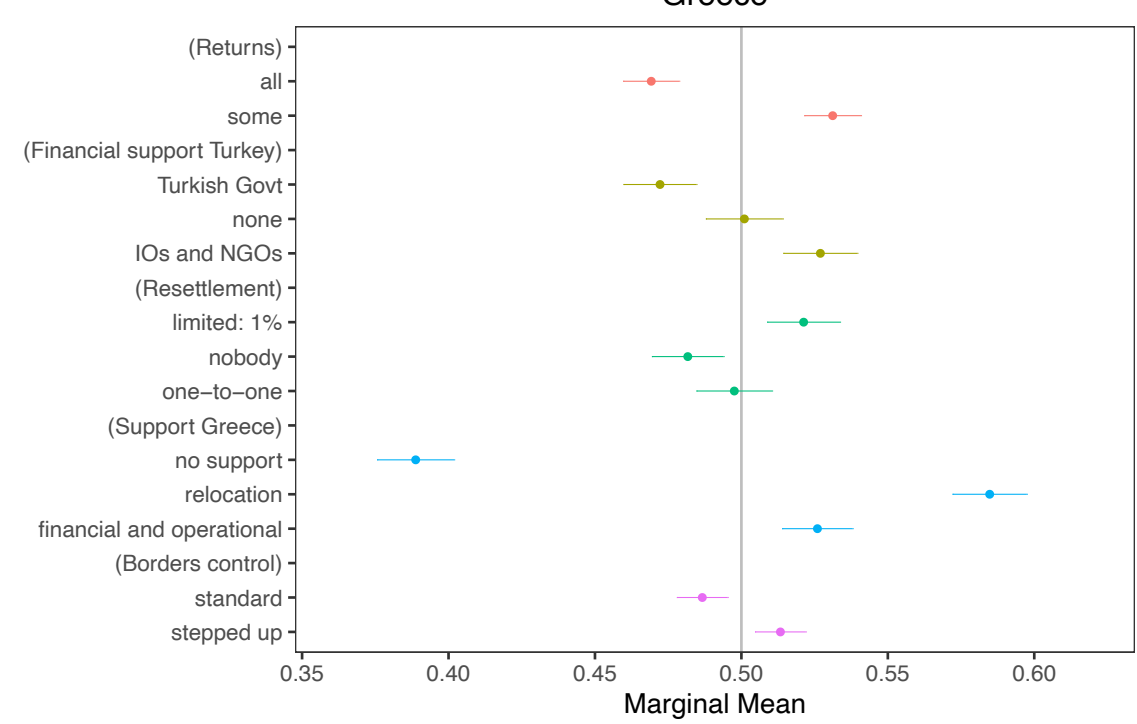

Figure A2. Marginal means 

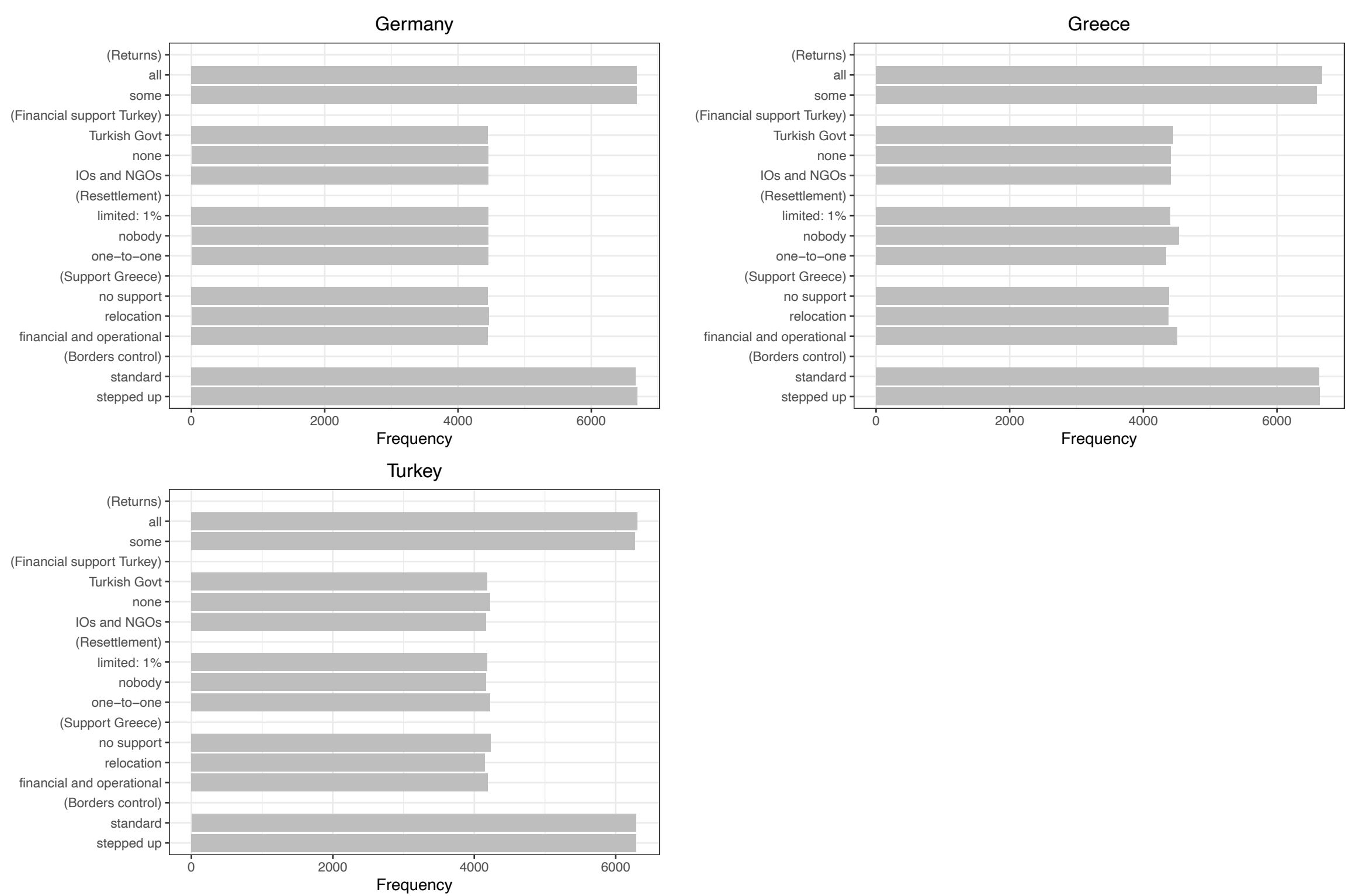

Figure A3. Frequencies of policy features 

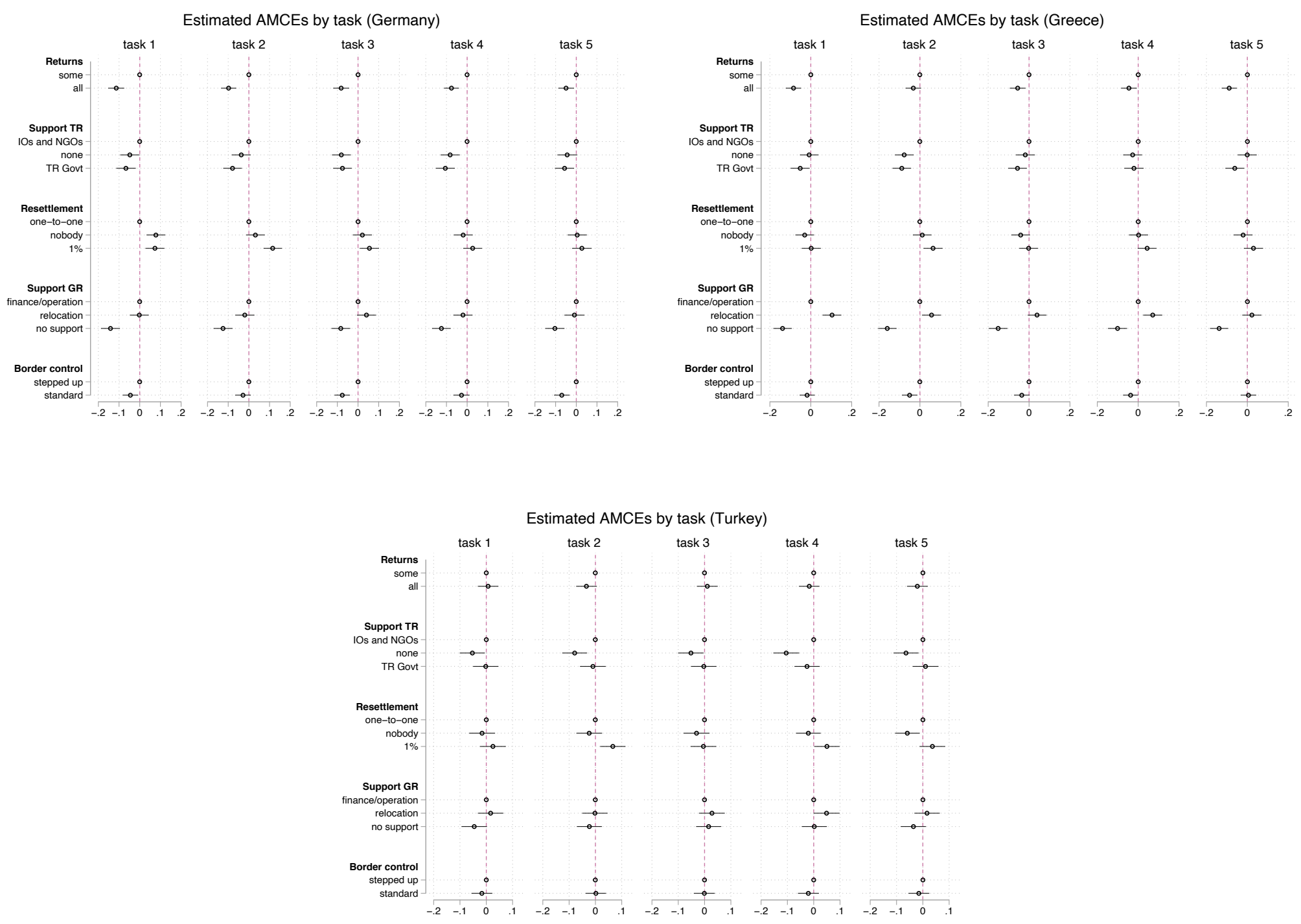

Figure A4. AMCEs estimated separately by conjoint task. Point estimates with $95 \%$ confidence intervals. 

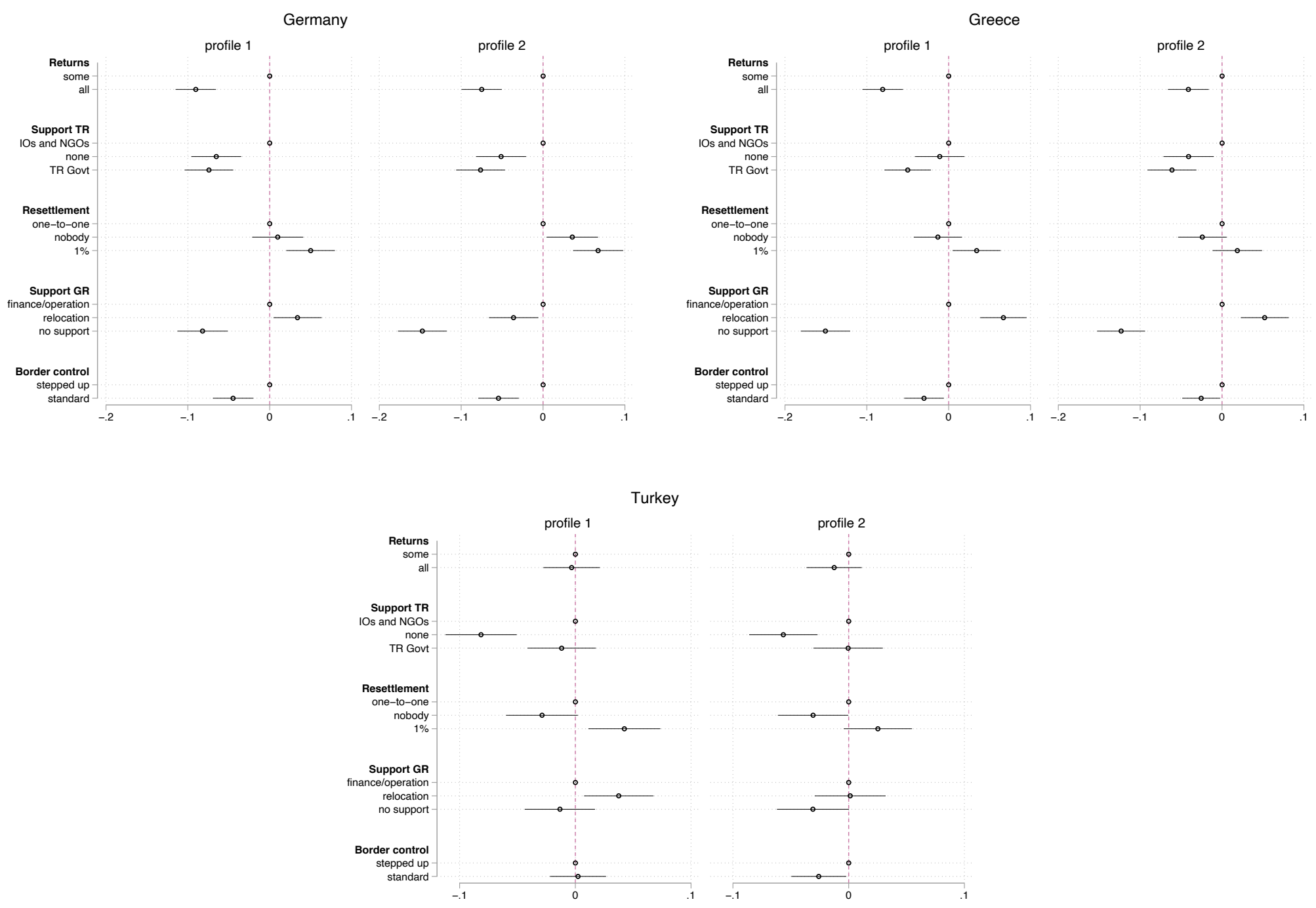

Figure A5. Estimated AMCEs by profile order. Point estimates with 95\% confidence intervals. 

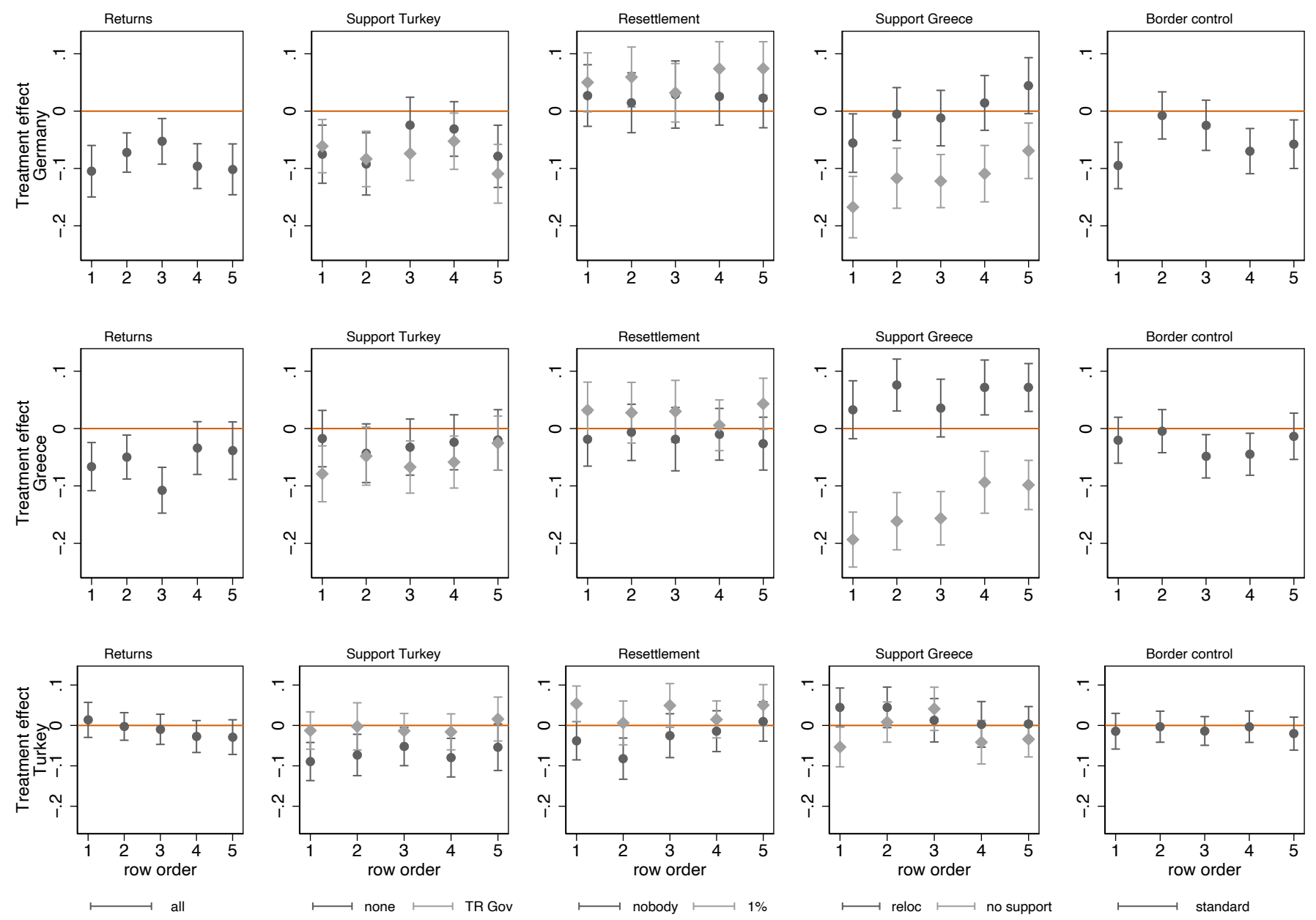

$\longmapsto$ reloc $\longmapsto$ no suppor

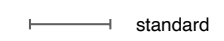

Figure A6. Estimated AMCEs by attribute order, i.e. by row in the conjoint table. Point estimates with $95 \%$ confidence intervals. 

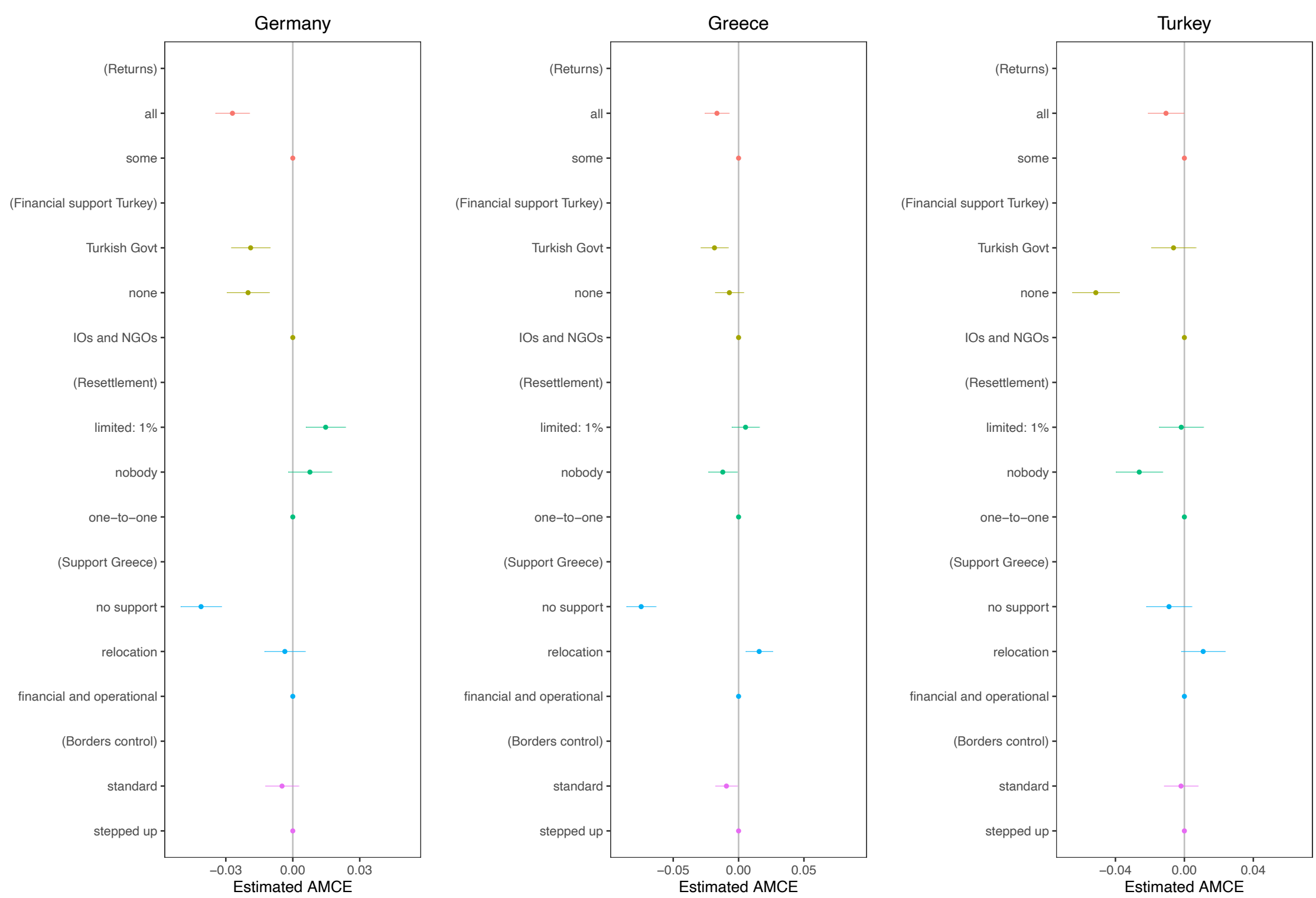

Figure A7. Results from models where the dependent variable is the rating outcome (rescaled to vary from 0 to 1 ). Point estimates with $95 \%$ confidence intervals. 

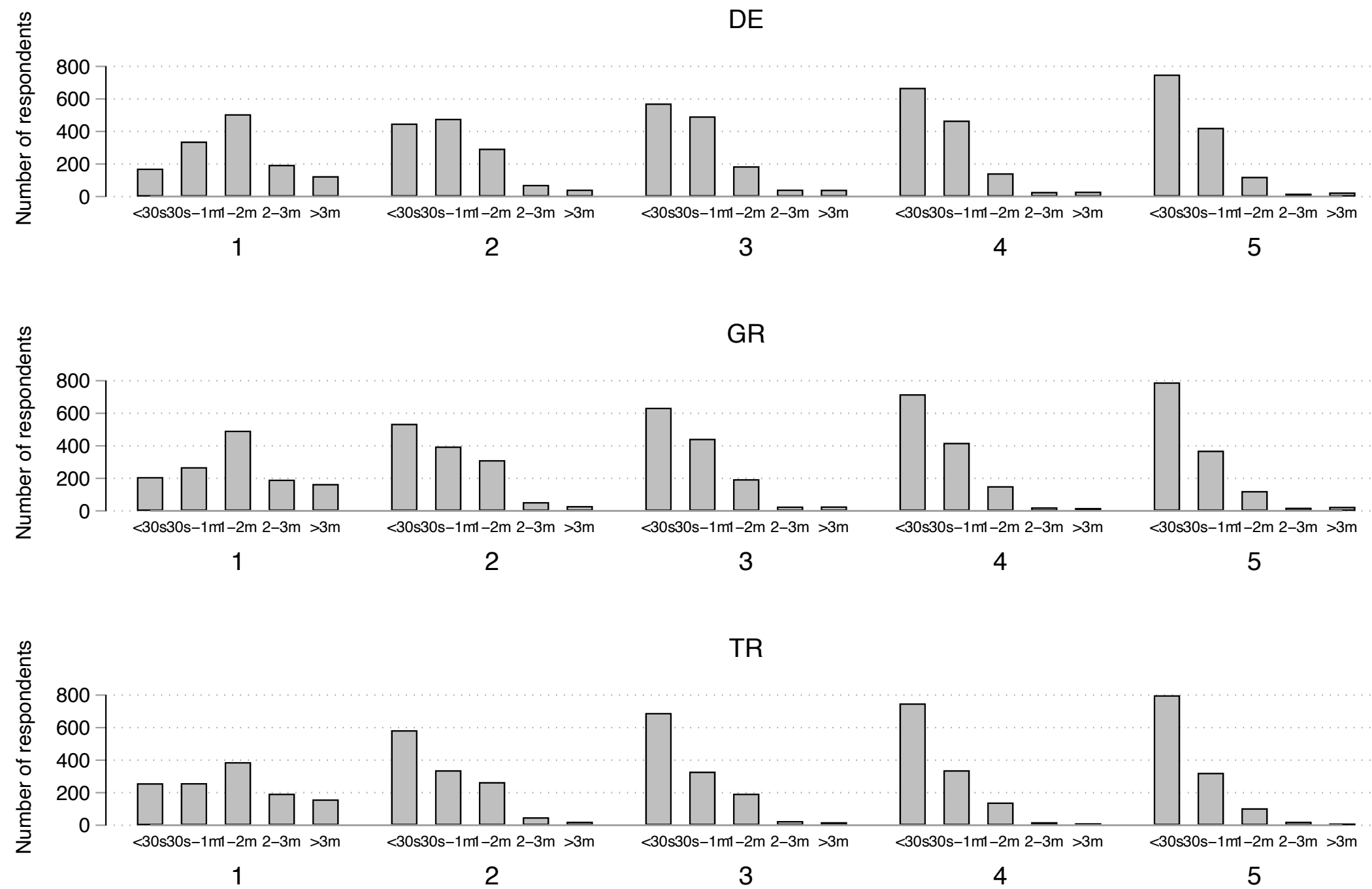

Figure A8. Time spent on each conjoint task 


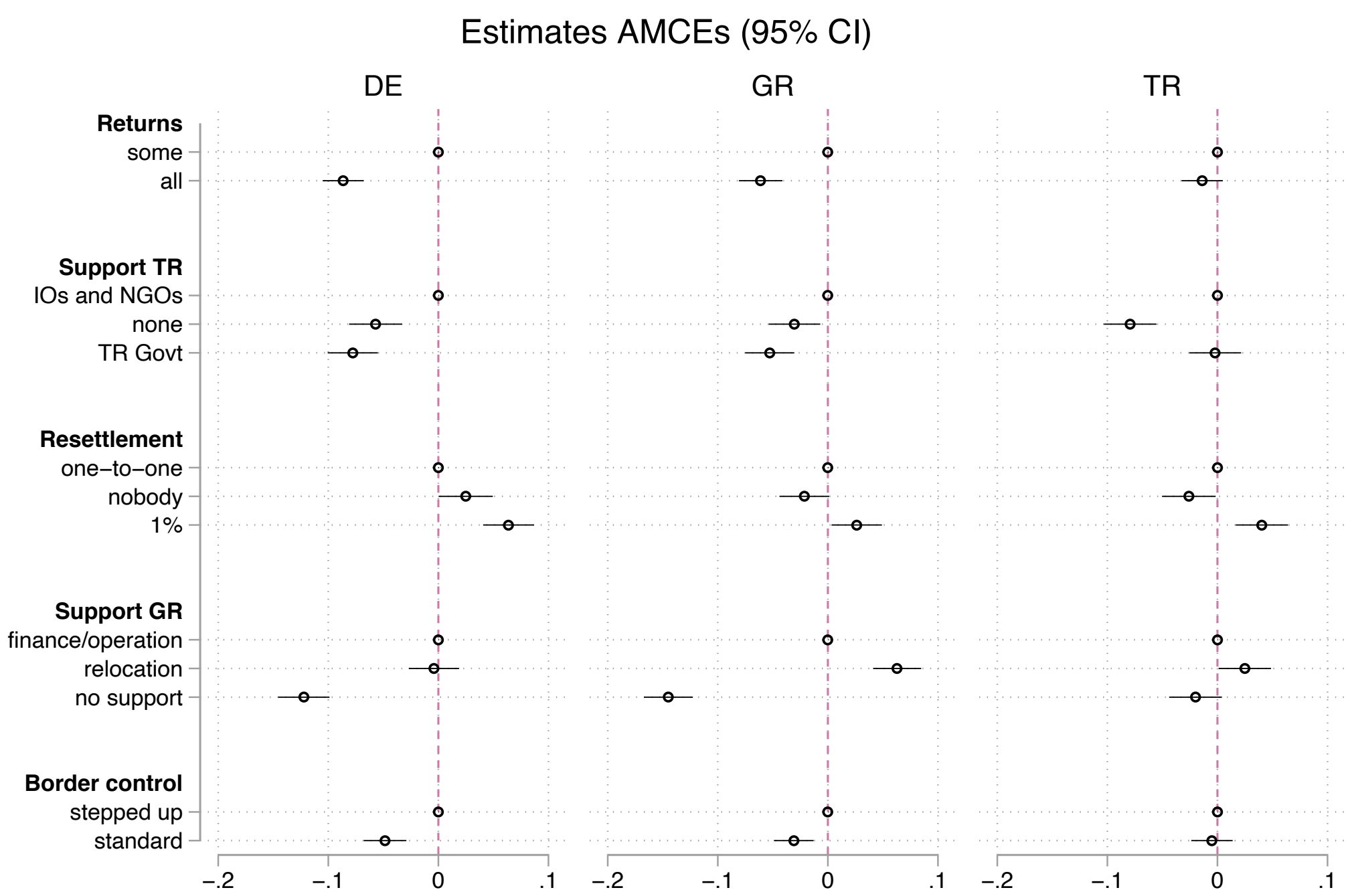

Figure A9. Estimated AMCEs from models with rating outcome (consistent ratings only), with 95\% confidence intervals 


\section{Tables}

Table A1. Summary statistics

\begin{tabular}{l|c|ccccc|ccc}
\hline & $\begin{array}{c}\text { Gender } \\
\text { Female }\end{array}$ & $\begin{array}{c}\text { Age } \\
18-24\end{array}$ & $\begin{array}{c}\text { Age } \\
25-34\end{array}$ & $\begin{array}{c}\text { Age } \\
\text { (15-44 }\end{array}$ & $\begin{array}{c}\text { Age } \\
45-54\end{array}$ & $\begin{array}{c}\text { Age } \\
55+\end{array}$ & $\begin{array}{c}\text { Education } \\
\text { Bellow upper } \\
\text { secondary }\end{array}$ & $\begin{array}{c}\text { Education } \\
\text { Upper } / \text { post- } \\
\text { secondary }\end{array}$ & $\begin{array}{c}\text { Education } \\
\text { Tertiary }\end{array}$ \\
\hline Germany & $51 \%$ & $10 \%$ & $16 \%$ & $15 \%$ & $20 \%$ & $39 \%$ & $5 \%$ & $61 \%$ & $35 \%$ \\
Greece & $49 \%$ & $12 \%$ & $19 \%$ & $25 \%$ & $25 \%$ & $20 \%$ & $4 \%$ & $30 \%$ & $66 \%$ \\
Turkey & $50 \%$ & $17 \%$ & $24 \%$ & $24 \%$ & $19 \%$ & $16 \%$ & $7 \%$ & $22 \%$ & $71 \%$ \\
\hline
\end{tabular}


Table A2. Balance checks

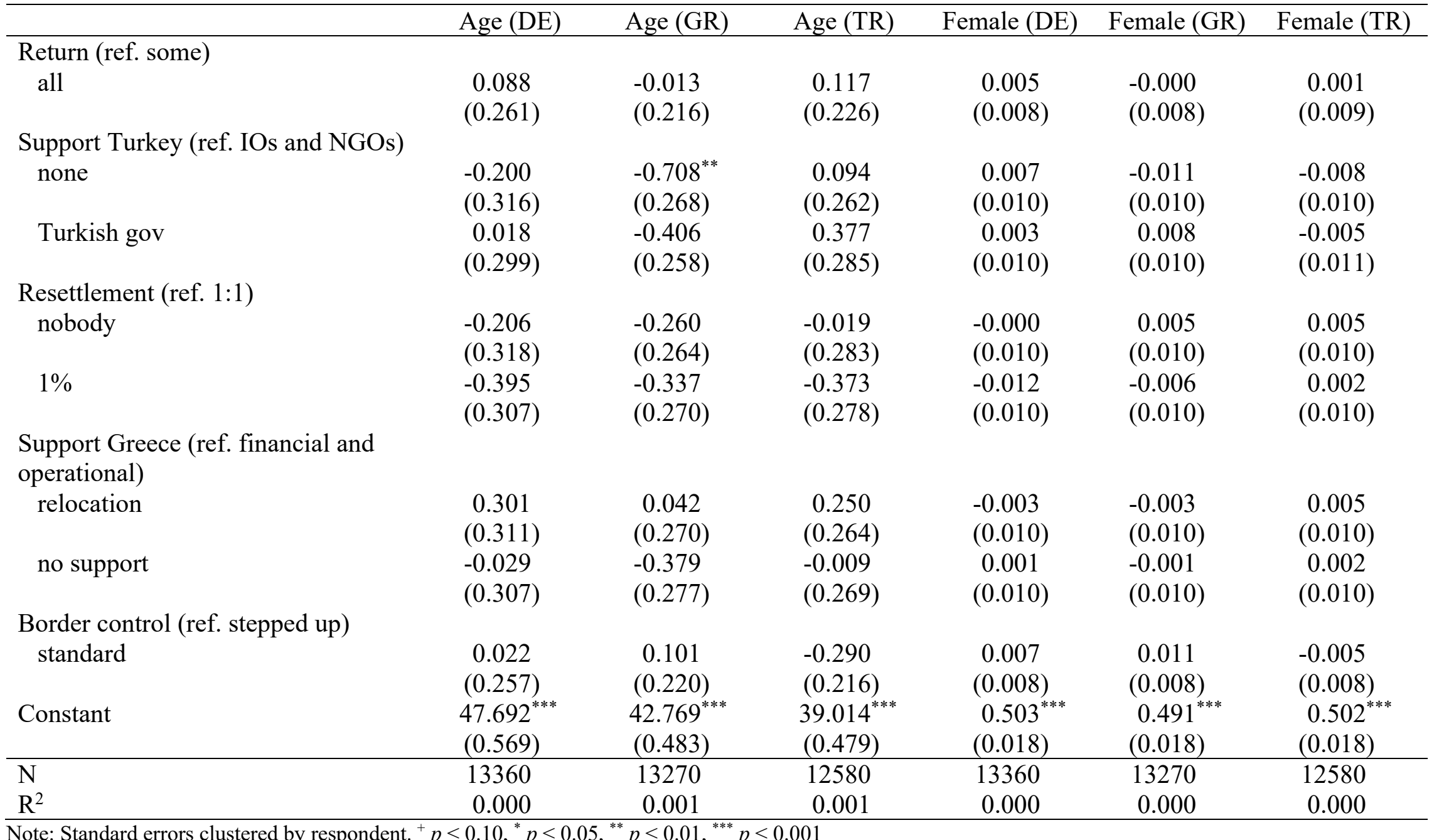


Table A2 (cont.) Balance checks

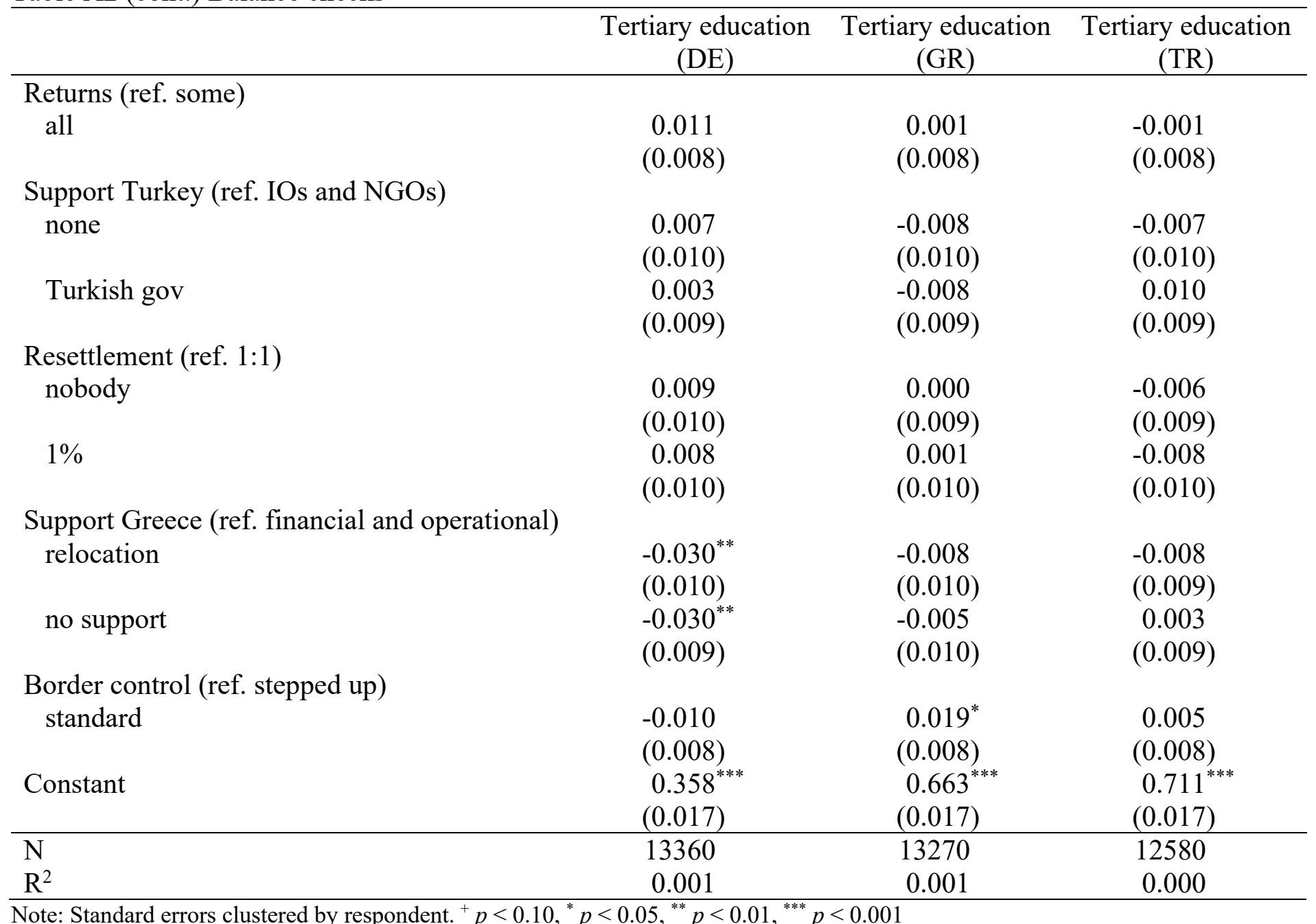


Table A3. Treatment effects (with covariate adjustment, German sample)

\begin{tabular}{lc}
\hline & Estimates \\
\hline Returns (ref. some) & $-0.083^{* * *}$ \\
all & $(0.009)$ \\
Financial support Turkey (ref. IOs and NGOs) & $-0.059^{* * *}$ \\
none & $(0.012)$ \\
& $-0.076^{* * *}$ \\
Turkish gov & $(0.011)$ \\
Resettlement (ref. 1:1) & $0.024^{*}$ \\
nobody & $(0.012)$ \\
& $0.060^{* * *}$ \\
$1 \%$ & $(0.011)$ \\
Support Greece (ref. financial and operational) & -0.001 \\
relocation & $(0.011)$ \\
no support & $-0.115^{* * *}$ \\
Border controls (ref. stepped up) & $(0.011)$ \\
standard & $-0.050^{* * *}$ \\
Tertiary education & $(0.009)$ \\
Constant & -0.001 \\
& $(0.001)$ \\
$\mathrm{R}^{2}$ & $0.623^{* * *}$ \\
\hline
\end{tabular}

Note: ${ }^{+} p<0.10,{ }^{*} p<0.05,{ }^{* *} p<0.01,{ }^{* * *} p<0.001$. Standard errors clustered by respondent. Tertiary education is a dummy variable taking the value 1 for respondents with tertiary education and the value 0 for all other respondents. 
Table A4. AMCEs across education groups

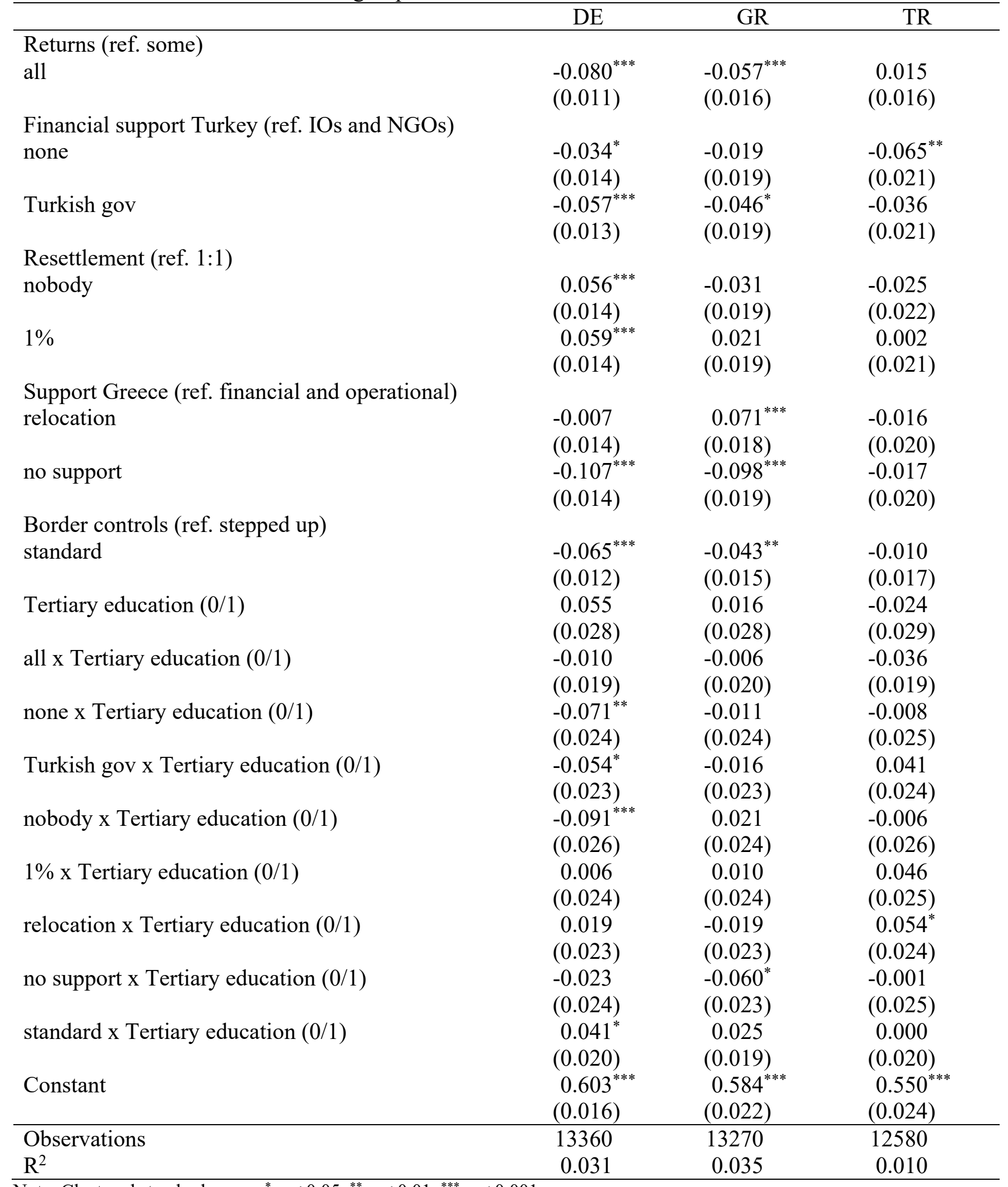

Note: Clustered standard errors. ${ }^{*} p<0.05,{ }^{* *} p<0.01,{ }^{* * *} p<0.001$ 


\section{References}

Bansak, Kirk, Jens Hainmueller and Dominik Hangartner. 2016. How economic, humanitarian, and religious concerns shape European attitudes toward asylum seekers. Science 354 (6309): 217-22.

Jenke, Libby, Bansak, Kirk, Hainmueller, Jens, and Dominik Hangartner. 2021. Using EyeTracking to Understand Decision-Making in Conjoint Experiments. Political Analysis 29: 75-101. 